\title{
Features caused by ground ice growth and decay in Late Pleistocene fluvial deposits, Paris Basin, France
}

\author{
Pascal Bertran ${ }^{\mathrm{a}, \mathrm{b}, *}$, Eric Andrieux ${ }^{\mathrm{b}, \mathrm{c}}$, Mark Bateman $^{\mathrm{c}}$, Marianne Font $^{\mathrm{d}}$, Kevin Manchuel ${ }^{\mathrm{e}}$, Deborah Sicilia ${ }^{\mathrm{e}}$ \\ a Inrap, 140 avenue du Maréchal Leclerc, 33130 Bègles, France \\ ${ }^{\mathrm{b}}$ PACEA, bâtiment B18, allée Geoffroy-Saint-Hilaire, 33615 Pessac, France \\ c Geography Department, University of Sheffield, Winter Street, Sheffield S10 2TN, UK \\ ${ }^{\mathrm{d}}$ M2C, UMR CNRS 6143, 24 rue des Tilleuls, 14000 Caen, France \\ e EDF, TEGG/Service Géologique Géotechnique, 905 Avenue du Camp de Menthe, 13097 Aix-en-Provence, France
}

\section{Introduction}

Over the past decade, the creation of a database of relict periglacial features in France allowed documentation of the maximum Pleistocene extent of permafrost and made it possible to delineate permafrost types at the scale of the whole territory (Bertran et al., 2014, 2017; Andrieux et al., 2016a, 2016b). Ice wedge pseudomorphs, which indicate at least widespread discontinuous permafrost, were only observed north of latitude $47.5^{\circ} \mathrm{N}$ in lowlands (Fig. 1). Farther south, between latitudes $47.5^{\circ} \mathrm{N}$ and $43.5^{\circ} \mathrm{N}$, the main features listed are involutions and thermal contraction cracks filled with aeolian sand (sand wedges) at the periphery of coversands. The lack of ice wedge pseudomorphs suggests that soil temperature was too high to allow ice bodies to grow over long time periods. Therefore, this latitudinal band is considered to have been affected by sporadic permafrost. South of $43.5^{\circ} \mathrm{N}$, no periglacial

\footnotetext{
* Corresponding author at: Inrap, 140 avenue du Maréchal Leclerc, 33130 Bègles, France.

E-mail address: pascal.bertran@inrap.fr (P. Bertran).
}

features have been reported, and permafrost was probably completely absent even during the coldest phases of the Glacial.

In the area affected by widespread permafrost, the existence of other types of ground ice (interstitial, segregation, injection, icing, firn) appears highly plausible by analogy with modern Arctic environments. Platy structures caused by segregation ice lenses in fine-grained sediments have been widely reported, particularly in loess (e.g., Van Vliet and Langohr, 1981; Van Vliet-Lanoë, 1992; Antoine et al., 1999). In contrast, no indisputable evidence of the growth or decay (thermokarst) of large bodies of segregation or injection ice is known. Potentially thermokarst structures have been reported in the literature but remain debated. Shallow rounded depressions attributed to the melting of pingos or lithalsas have been described by many authors, particularly in the vicinity of Bordeaux and in the Landes district (SW France) (Boyé, 1958; Legigan, 1979), as well as in the Paris Basin (Michel, 1962, 1967; Courbouleix and Fleury, 1996; Lécolle, 1998; Van VlietLanoë et al., 2016). In SW France, a periglacial origin of the depressions, locally called 'lagunes', has recently been invalidated (Texier, 2011; Becheler, 2014) and has been shown to be mainly related to limestone 


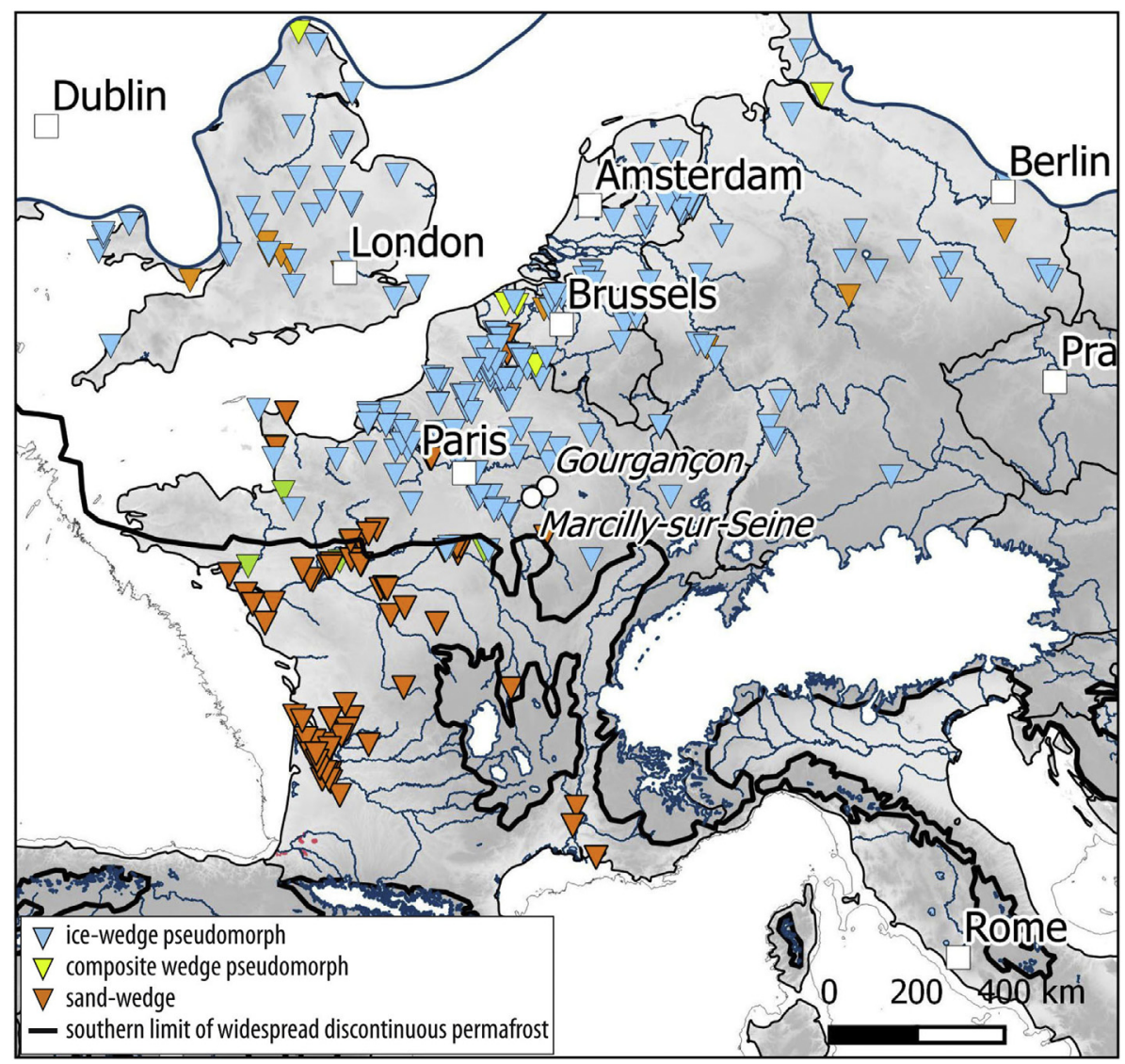

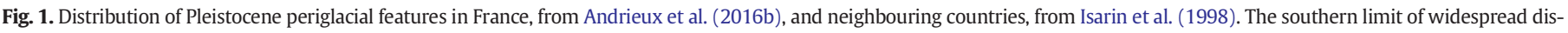

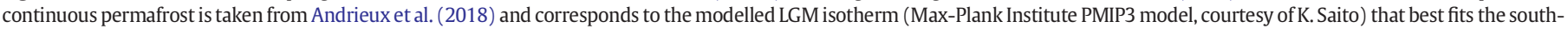

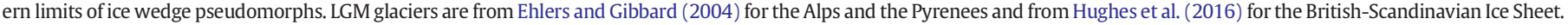

dissolution (doline) below the coversands. Some shallow depressions correspond to deflation hollows upwind from parabolic dunes or to flooded areas following the dam of small valleys by dunes (Sitzia, 2014). In the Paris Basin, the authors acknowledge the difficulty of demonstrating a thermokarst origin. Alternative hypotheses (karst, anthropogenic activity) remain problematic to eliminate in the majority of cases. Detailed analysis and dating of the filling of depressions from NE France (Etienne et al., 2011) has, for example, led to an anthropogenic origin (marl extraction to amend fields during the Medieval period).

Convincing thermokarst remnants have been identified in a German loess sequence at Nussloch in the Rhine valley, ca. $50 \mathrm{~km}$ from the French border (Antoine et al., 2013; Kadereit et al., 2013). The structures correspond to gullies some tens of metres in width with ice wedge pseudomorphs locally preserved at the bottom. They are interpreted as erosional features caused by the melting of an ice wedge network on the slope according to a well-documented model in modern environments (Seppälä, 1997; Fortier et al., 2007). Until now, no similar structure has been reported from the French territory.

As part of the SISMOGEL project (which involves Electricity De France (EDF), Inrap, and the universities of Bordeaux and Caen), various sites showing deformations in Quaternary sediments were reevaluated. Two of them, Marcilly-sur-Seine and Gourgançon, located in an alluvial context in the Paris Basin, have been studied in detail through the survey of quarry fronts and are the subject of this article. Similar sites are then identified in northern France by using information from the aerial photographs available on Google Earth, topographical data from the 5-m DEM of the Institut Géographique National (IGN), and borehole data stored in the Banque du Sous-Sol (BSS) of the Bureau des Recherches Géologiques et Minières (BRGM). Overall, this study provides new evidence of permafrost-induced ground deformations in France and strongly suggests that thermokarst played a significant and probably largely underestimated role in the genesis of Late Pleistocene landscapes.

\section{Geomorphological context of the study region}

The investigated sites are located 110 to $130 \mathrm{~km}$ ESE from Paris in the upper Cretaceous chalk aureole of the basin (Fig. 2). This area remained unglaciated during the Pleistocene cold periods but experienced phases of permafrost development. Because of limited loess deposition (the area was at the southern margin of the north European loess belt; Bertran et al., 2016), remnants of periglacial landscapes are still easily readable in aerial photographs and most of the polygons caused by thermal contraction cracking of the ground and soil stripes caused by active layer cryoturbation found in France from aerial survey are concentrated in this latitudinal band (Andrieux et al., 2016a). Single grain OSL dating of the infilling of sand wedges and composite wedge pseudomorphs from sites located in the Loire valley showed that thermal contraction cracking occurred repeatedly during Marine Isotopic Stages (MIS) 4, 3, 2, and early MIS 1 (Younger Dryas) (Andrieux et al., 2018). In contrast, available chronological data on ice wedge pseudomorphs preserved in loess sequences of northern France strongly suggest that perennial ice (i.e., permafrost) was able to develop only during shorter periods of MIS 4 to 2 and that the largest pseudomorphs date to between 21 and 31 ka (Locht et al., 2006; Antoine et al., 2014). By contrast to northern Europe where most of the identified thermokarst structures have been dated to the very end of MIS 2 and the Lateglacial (Pissart, 2000b), similar structures in the Paris Basin, if present, should be significantly older and, thus, may potentially have 


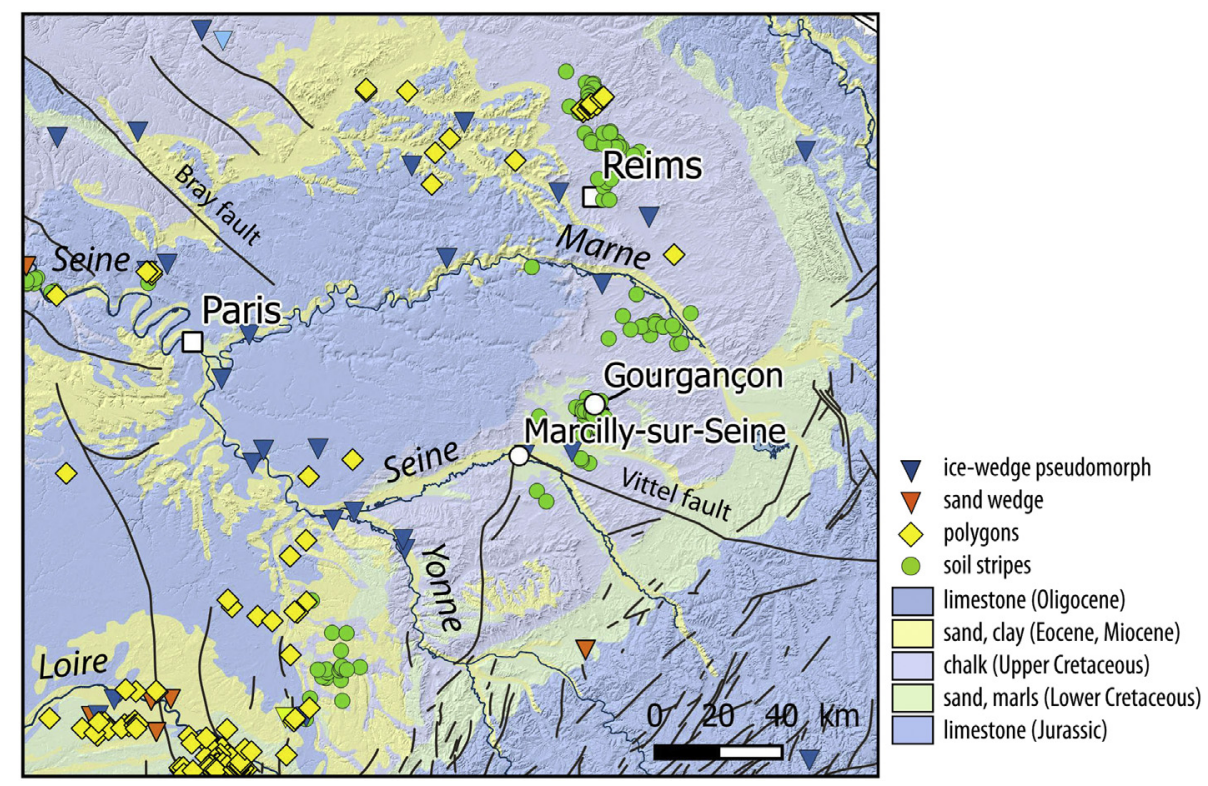

Fig. 2. Simplified geological map of the Paris Basin (BRGM, infoterre.brgm.fr), and location of the study sites. The periglacial features listed in Andrieux et al. (2016b) are indicated.

left much poorly preserved evidence in the landscape. Thermokarst develops today in ice-rich permafrost, typically in poorly drained valley bottoms, large deltas, and lake margins and in Yedoma-type formations in high latitude regions where abundant syngenetic ice formed during the Pleistocene. The Weichselian alluvial terraces (generally referred to as Fy on geological maps) of the main rivers crossing the Paris Basin are potentially suitable contexts for searching thermokarst structures. These terraces have been largely exploited for gravel production around Paris since the 1950s and provided evidence of periglacial structures (Michel, 1962, 1967). These quarries are no more accessible today. The quarries of Marcilly-sur-Seine (still in activity) and Gourgançon are located upstream and provide a good opportunity to investigate former potentially ice-rich fluvial deposits.

\section{Methods}

The sections were water jet and manually cleaned, and detailed photographs were taken. The stratigraphy was based on visual inspection and measurement of the sections. Three samples for grain size analysis were taken from the basal lacustrine unit in Marcilly-sur-Seine. The samples were processed in the PACEA laboratory (Universite de Bordeaux, France) using a Horiba LA-950 laser particle size analyser. The pretreatment includes suspension in sodium hexametaphosphate $(5 \mathrm{~g} / \mathrm{L})$ and hydrogen peroxide (35\%) for $12 \mathrm{~h}$, and $60 \mathrm{~s}$ of ultrasonification to achieve optimal dispersion. The Mie solution to Maxwell's equations provided the basis for calculating particle size using a refractive index of 1.333 for water and $1.55 \mathrm{i}-0.01 \mathrm{i}$ for the particles. An undisturbed block of lacustrine sediment was also sampled and vacuum impregnated with polyester resin following the method described by Guilloré (1980) to prepare a thin section.

The AMS radiocarbon dating on bulk lacustrine silt sampled in Marcilly-sur-Seine was made by Beta Analytic (Miami, USA). Optically Stimulated Luminescence (OSL) dating was carried out on sand from the same site at the Luminescence Dating Laboratory of the University of Sheffield (UK). The OSL sample was collected by hammering into the freshly exposed section a metal tube $(60 \mathrm{~mm}$ in diameter, $250 \mathrm{~mm}$ long). To avoid any potential light contamination that may have occurred during sampling, $2 \mathrm{~cm}$ of sediment located at the ends of the tube was removed. The remainder of the sample was sieved and chemically treated to extracts 90 to $180 \mu \mathrm{m}$ diameter quartz grains as per Bateman and Catt (1996).
The dose rate was determined from analysis undertaken using inductively coupled plasma mass spectroscopy (ICP-MS) at SGS Laboratories, Montréal (Canada). Adjacent lithostratigraphic units of host sediment were also analysed to establish their $\gamma$ dose contribution to the sample dated as per Aitken (1985). Conversions to annual dose rates were calculated as per Adamiec and Aitken (1998) for $\alpha$ and $\gamma$, and per Marsh et al. (2002) for $\beta$, with dose rates attenuated for sediment size and palaeomoisture contents (Table 1). For the latter, given the presence in the sediment of features characteristic to the melting of ice, a value of $20 \pm 5 \%$ was assumed. This is a value close to the saturation of sediment in water, and the absolute error of $\pm 5 \%$ is incorporated to allow for past changes. Cosmic dose rates were determined following Prescott and Hutton (1994).

The OSL measurements were undertaken on $9.6 \mathrm{~mm}$ single aliquot discs in a Risø automated luminescence reader. The purity of extracted quartz was tested by stimulation with infrared light as per Duller (2003). Equivalent dose (De) determination was carried out using the Single-Aliquot Regenerative-dose (SAR; Murray and Wintle, 2003; Table 1). The sample displayed OSL decay curves dominated by the fast component, had good dose recovery, low thermal transfer, and good recycling. Twenty-four De replicates were measured for the sample, and these showed the De distribution was unimodal with a low overdispersion (OD; $<20 \%$ ), therefore the age was extracted using the Central Age Model (CAM; Galbraith et al., 1999). The final age, with $1 \sigma$ uncertainties, is therefore considered a good burial age for the sediment sampled.

\section{Results}

\subsection{Marcilly-sur-Seine}

\subsubsection{Geomorphological setting}

Marcilly-sur-Seine $\left(48.5411^{\circ} \mathrm{N}, 3.7234^{\circ} \mathrm{E}\right)$ is located in the Seine valley near its confluence with the Aube River in the Paris Basin (Fig. 2). The local substrate comprises alluvium overlying upper Cretaceous chalk. The studied cross sections cut the Fy terrace (geological map at 1:50,000, infoterre.brgm.fr), which dominates the Holocene floodplain (Fz) by 2 to $3 \mathrm{~m}$ (Fig. 3). The wide Fy terrace exhibits an undulating topography as shown by the 5 -m DEM (IGN), which contrasts with the even topography of the Fz floodplain. The main recognisable topographical features consist either in shallow depressions $<1 \mathrm{~m}$ deep or in small 
Table 1

OSL-related data and age of the sampled site.

\begin{tabular}{|c|c|c|c|c|c|c|c|c|c|}
\hline Sample code & $\mathrm{K}(\%)$ & $\mathrm{U}(\mathrm{ppm})$ & Th (ppm) & Cosmic dose $\left(\mu \mathrm{Gy} \mathrm{a}^{-1}\right)$ & Total dose $\left(\mathrm{Gy} \mathrm{kyr}^{-1}\right)^{\mathrm{a}}$ & $\mathrm{D}_{\mathrm{e}}(\mathrm{Gy})^{\mathrm{b}}$ & $\mathrm{N}^{\mathrm{c}}$ & OD (\%) & Age (ka) \\
\hline Shfd17101 & 0.6 & 1.37 & 4.20 & $178 \pm 9$ & $0.94 \pm 0.05$ & $15.59 \pm 0.23$ & 24 & 9 & $16.6 \pm 0.90$ \\
\hline
\end{tabular}

conical mounds especially on the edge of the terrace (Fig. 4). Shallow sinuous channels also cross the entire surface. In aerial photography, Fy appears irregularly covered with subcircular or elongated dark spots a few tens of metres to $150 \mathrm{~m}$ in length (Fig. 5). This type of structure is lacking on the Fz floodplain, which is crossed by large abandoned channels filled with fine-grained, dark-coloured sediments.
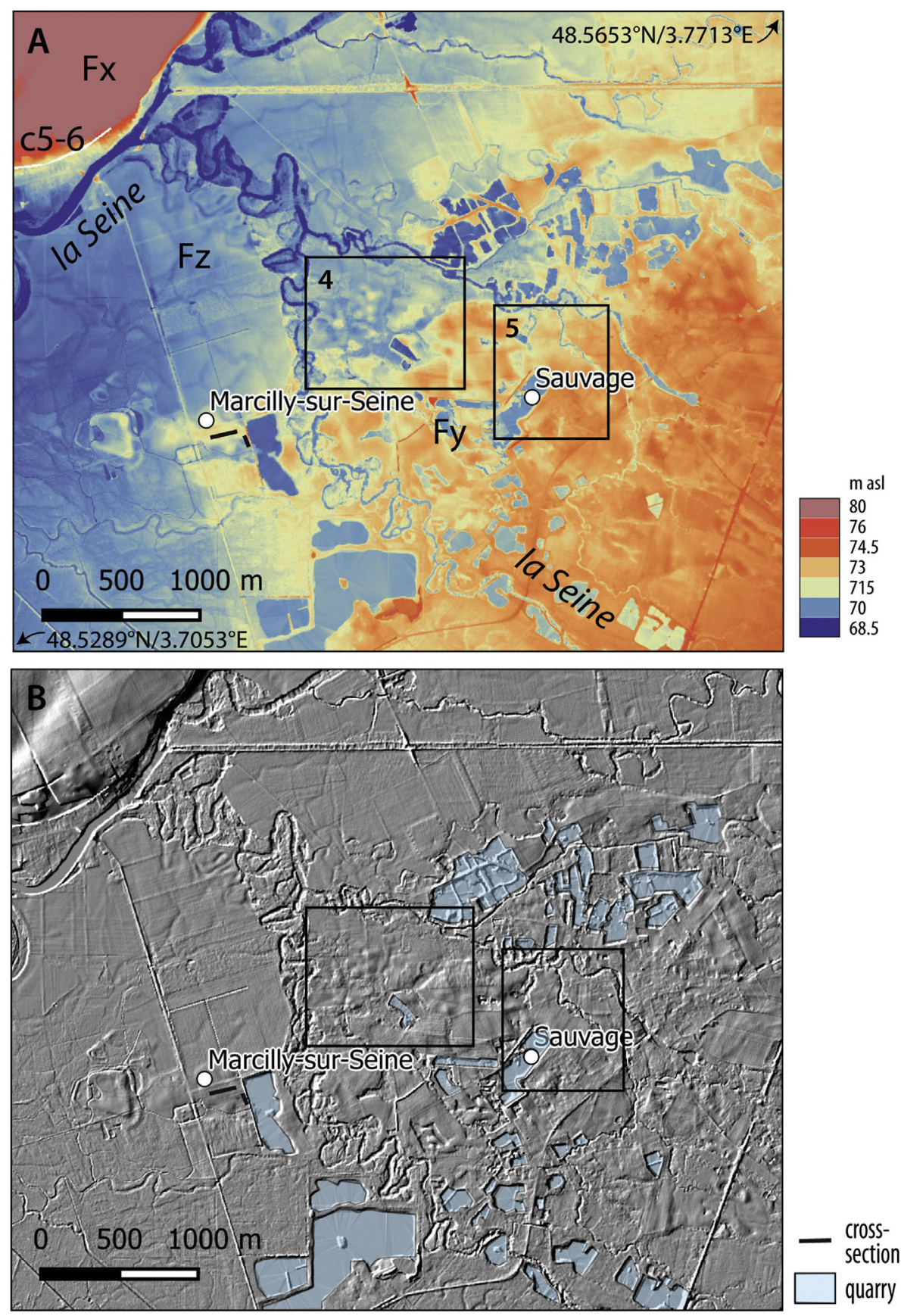

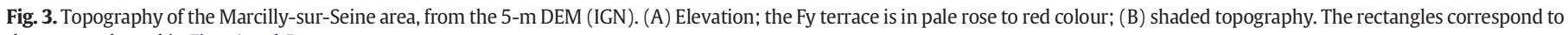
the areas enlarged in Figs. 4 and 5. 

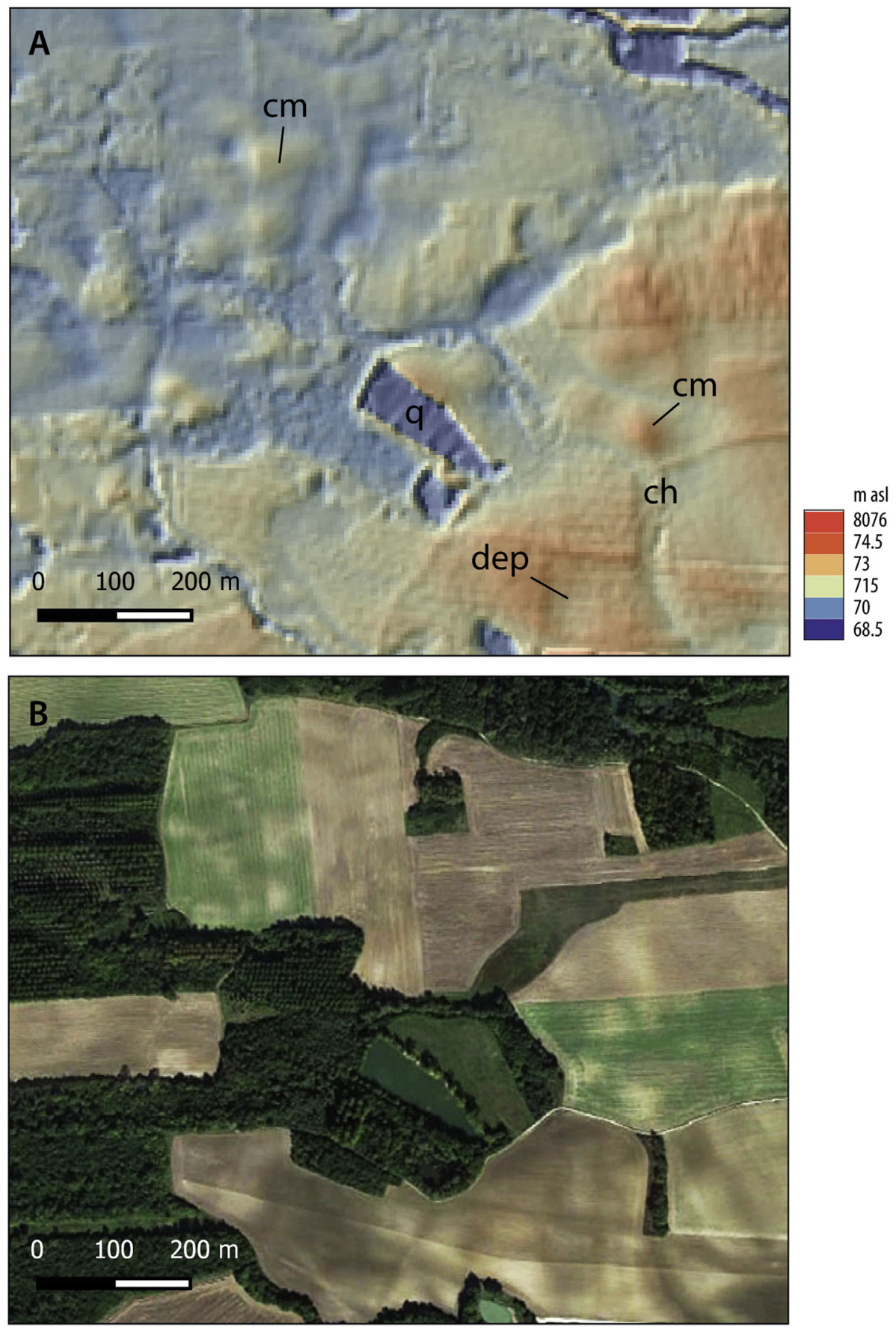

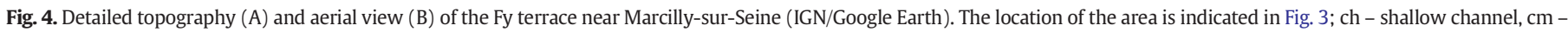
conical mound, dep - depression, q - quarry.

\subsubsection{Stratigraphy}

The observations were made on two trenches, the main (Section 1) about $2 \mathrm{~m}$ deep and $100 \mathrm{~m}$ long oriented east/west, the other (Section 2) $1.5 \mathrm{~m}$ deep and $28 \mathrm{~m}$ long oriented northwest/southeast. The stratigraphy of Section 1 comprises the following units, from the bottom to the top (Fig. 6):

[1] Sandy gravel alluvium. They are only punctually exposed at the surface in the quarry and are not visible in the trench. When visible, the dominant lithofacies (Miall, 1996) consists of trough cross-bedded gravel (Gt) with interstratified sand beds. According to available boreholes from the BSS and observation of the main quarry front, the alluvial deposits form a 5-7 m thick sheet overlying the chalk substrate.

[2] A laminated silt unit up to $2 \mathrm{~m}$ thick. The laminae are a few millimetres to $1 \mathrm{~cm}$ thick (Fig. 7A). The grain size is polymodal (probably because of the mixing of different laminae during sampling), and the main modes range between $13 \mu \mathrm{m}$ (fine silt) and $80 \mu \mathrm{m}$ (fine sand) (Fig. 8). Small fragments of vegetal tissues and insect cuticle are scattered in the detrital material (Fig. 9). This unit is interpreted as organic-poor lake deposits (Fl). A root porosity associated with ferruginous precipitation is also present but poorly developed. The upper part of this unit is structured in millimetre-thick lamellae (platy structure) caused 


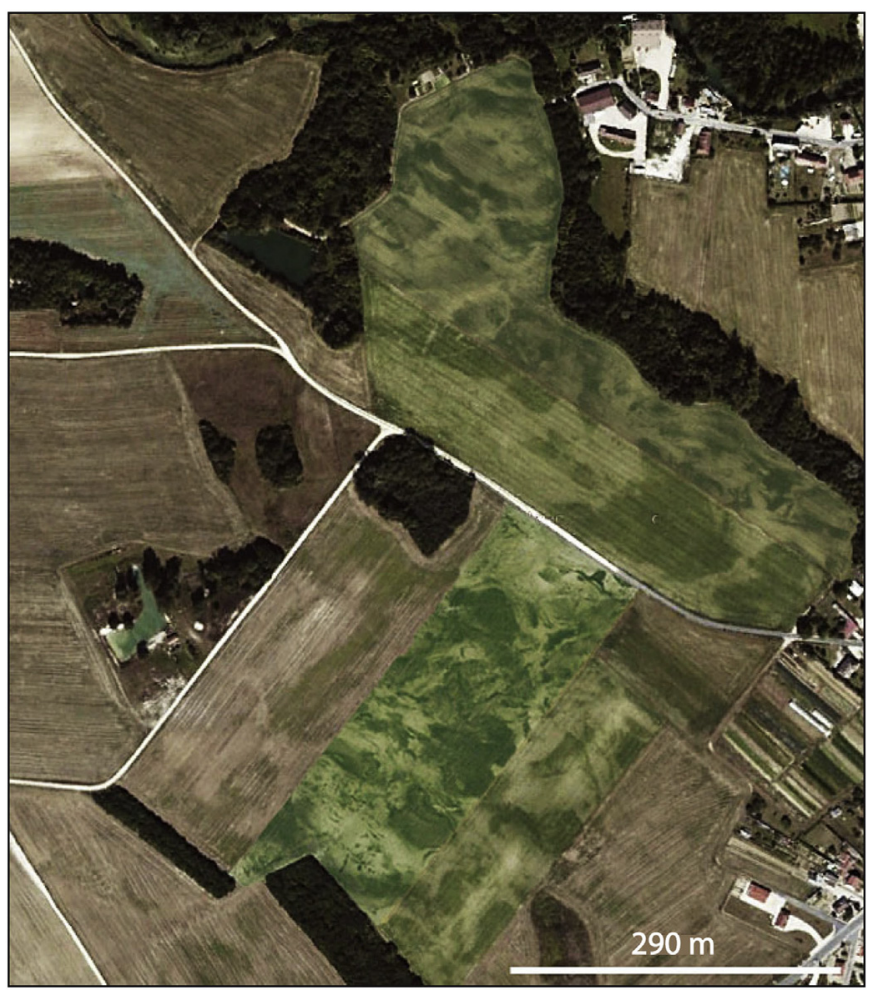

Fig. 5. Composite aerial view (IGN/Google Earth) of the Fy terrace near Saint-Just-Sauvage. The location of the area is indicated in Fig. 3.

by segregation ice lenses (Fig. 7B), and the lamination is totally obliterated (facies Fm).

[3] A sandy gravel unit (Gt, Sh) about 1 m thick, showing an upward fining trend (Fig. 7C). It corresponds to fluvial deposits that fill a channel eroding the underlying fine-grained unit. A thin ferruginous pan develops at the contact between the units.

[4] Massive sandy gravel deposits $(\mathrm{Gm}) 1 \mathrm{~m}$ thick overlying the alluvium. Locally, the sediment contains a large proportion of fine particles, and the gravels are scattered in a sandy silt matrix (matrix support, Dmm). Some sand levels form involutions with a massive structure (facies $\mathrm{Sm}$ ). This unit is interpreted as slumped alluvial and lacustrine deposits.

[5] Sand (Sh) and laminated or massive and silt deposits (Fl, Fm) with a platy structure unconformably cover unit [2] in the western part of the trench, where they can reach $2 \mathrm{~m}$ in thickness. This unit also corresponds to lake deposits. Because of truncation caused by quarry works, its stratigraphical relationship with units [3] and [4] remains unclear. We suppose here that unit [5] postdates unit [3].

\subsubsection{Deformation}

Abundant deformation structures can be observed throughout the trench. They consist of:

- A vertical structure about $0.4 \mathrm{~m}$ in width cutting through the basal grey blue lacustrine silt [unit 2] and filled with massive oxidized silt (Fig. 7D). The surrounding beds are curved downward symmetrically on either side of the structure. This depression, visible on both sides of the trench, is interpreted as an ice wedge pseudomorph. Approximately $10 \mathrm{~m}$ to the west, a second depression may correspond to another ice wedge pseudomorph.

- Ductile deformation affects the deposits, particularly in the eastern part of the trench. It can be seen both in the silt [2] and the sandy gravel [3] units, which form a recumbent fold (Fig. 10A). The slumped levels [4] overlay the folded unit. These features testify to the deformation of water-saturated sediments.

- Faults intersect the deformed beds. The faults are predominantly normal and indicate the collapse of sediments above the ice wedge pseudomorphs over a width of several metres. Laterally, conjugate normal faults delineate small grabens in the lake silts due to lateral spreading of the deposits.

- Cracks without vertical displacement, sometimes underlined by secondary carbonate accumulation, develop from the top of the section. They are associated with a well-developed platy structure. The fissures are about $1.5 \mathrm{~m}$ high and are a few metres apart. They are interpreted as thermal contraction cracks postdating sediment deformation.

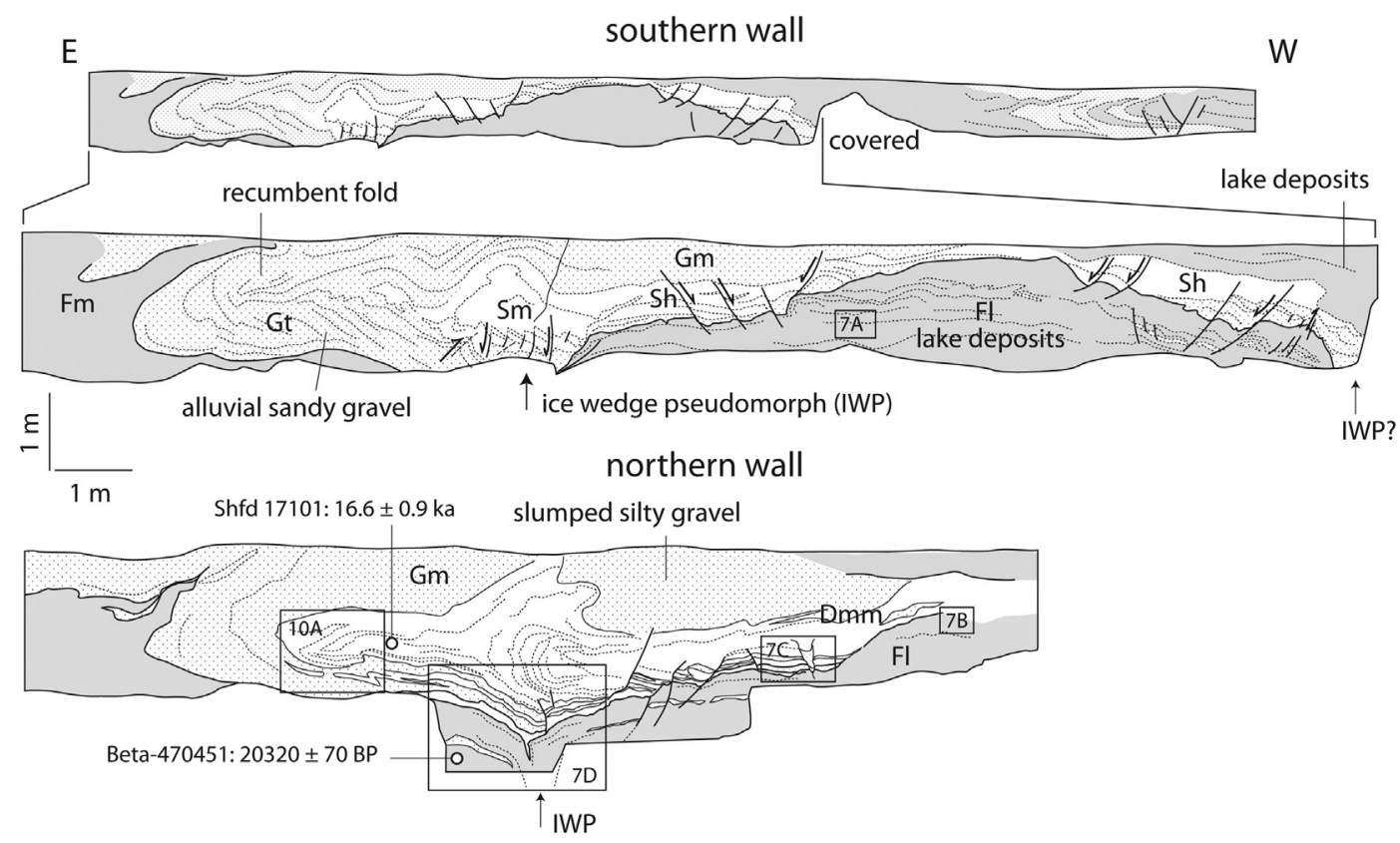

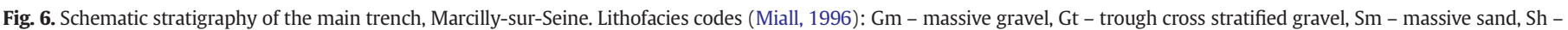
horizontally bedded sand, Fm - massive silt, Fl - laminated silt, Dmm - diamictic unit. The rectangles indicate the location of the photographs shown in Figs. 7 and 10. 

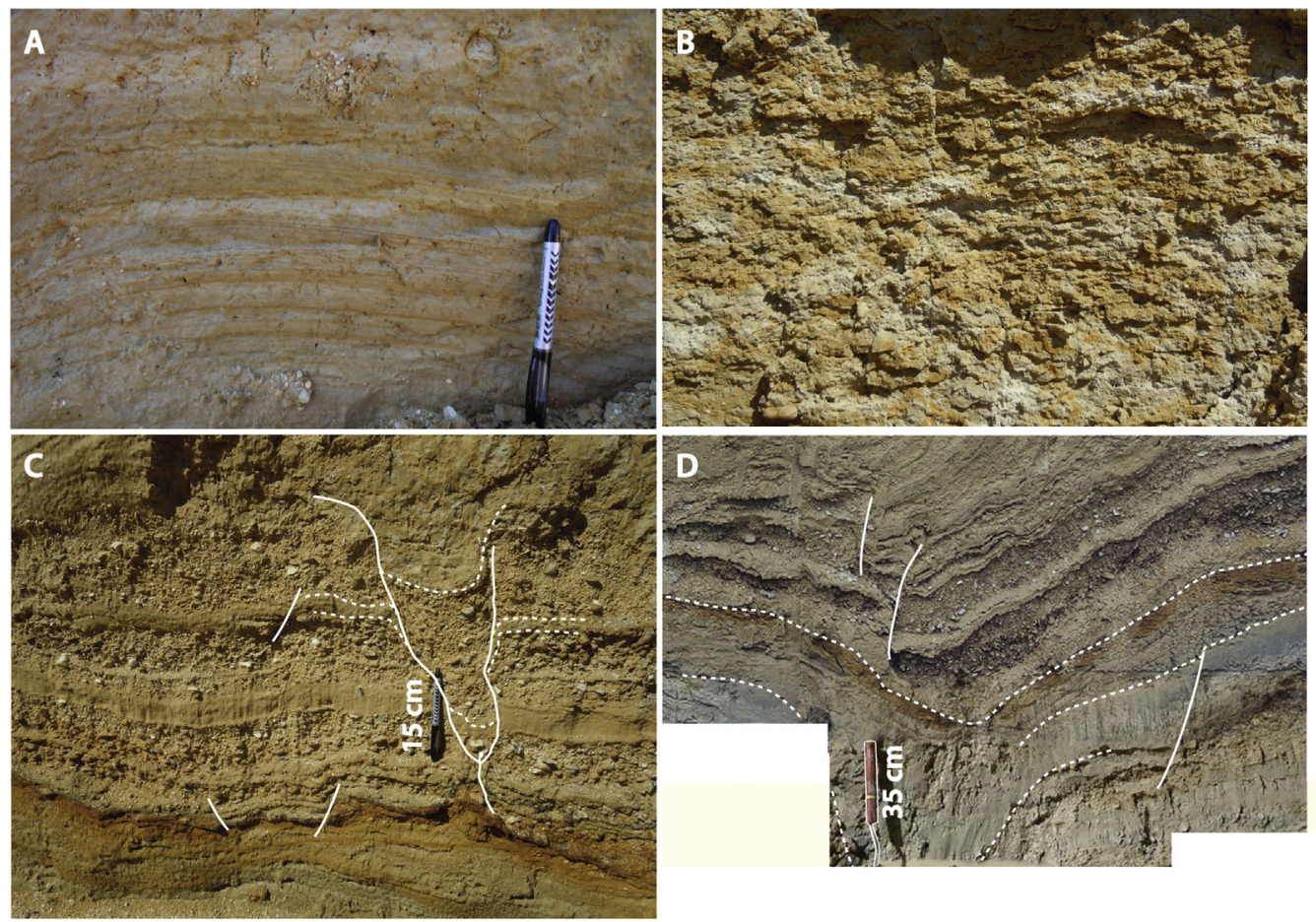

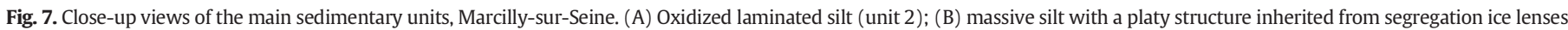
(top of unit 2); (C) bedded sand and fine gravel (unit 3); (D) deformed silt and bedded sand above an ice wedge pseudomorph. The location of the photographs is shown in Fig. 6.

In the western part of the trench, the section shows laminated silts (unit [5]) extending over several tens of metres. This unit is locally affected by normal faults with an offset of a few centimetres. A recumbent fold involving sand and silt beds is also visible (Fig. 6). At the western end, a small cross-section transverse to the main trench exposes a sandy gravel unit showing planar cross stratification with a dip of 30 to $33^{\circ}$. A tilted block of bedded sand is interstratified in this unit, which is interpreted as a small delta (Fig. 10B). Laterally, laminated silts cover the deltaic sands. The beds show a $20^{\circ}$ plunge but become progressively horizontal about $10 \mathrm{~m}$ to the east (Fig. 10C). The lack of onlap structures indicates that the plunge resulted mostly from post-sedimentary deformation caused by the collapse of the central part of the lake deposits.

The second trench (Section 2) also shows strongly deformed sandy gravel interstratified with fine-grained lake deposits (Fig. 11). Deformation is pervasive in this trench and in other locations in the quarry. It comprises (i) inverse faults associated with the subsidence of sandy gravel units (Fig. 12A), (ii) overturned folds in sandy gravel or silt (Fig. 12B), (iii) involutions, and (iv) tilted and faulted deltaic sands (Fig. 12C).

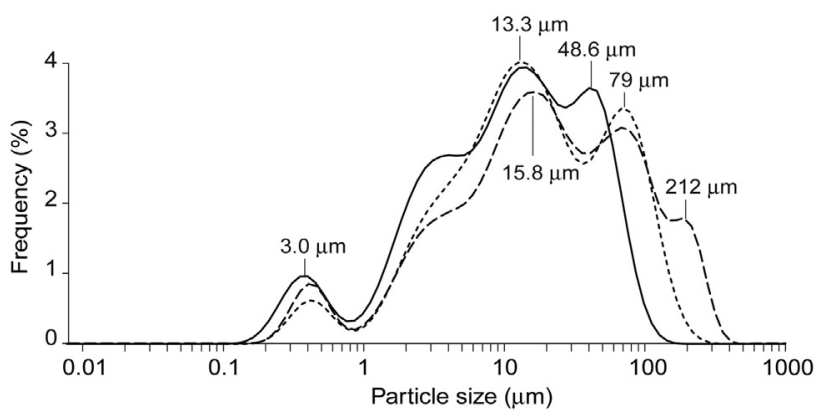

Fig. 8. Grain-size distribution of three samples representative of unit [2] lake deposits, Marcilly-sur-Seine.
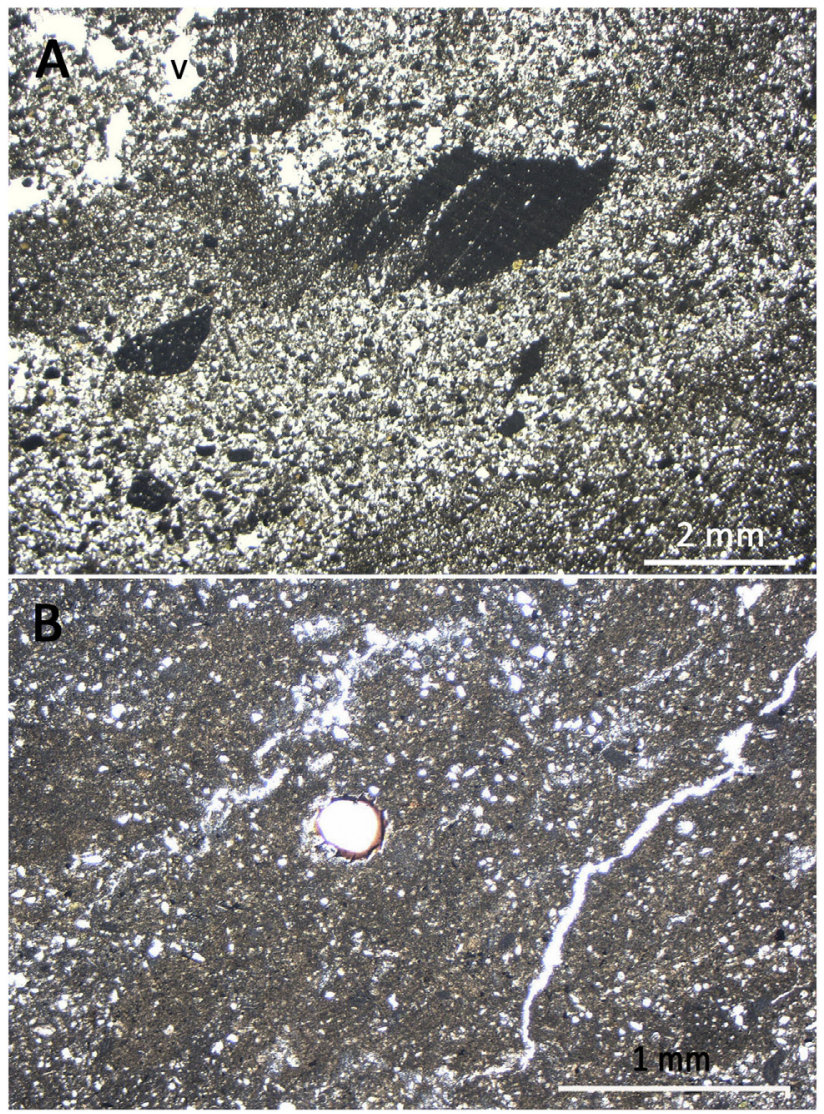

Fig. 9. Microfacies of lake deposits, unit [2], Marcilly-sur-Seine, Plane Polarised Light. (A) Laminated silts; the lamination is partly disrupted (v: vesicles); (B) fragment of insect cuticle in laminated fine silts. 

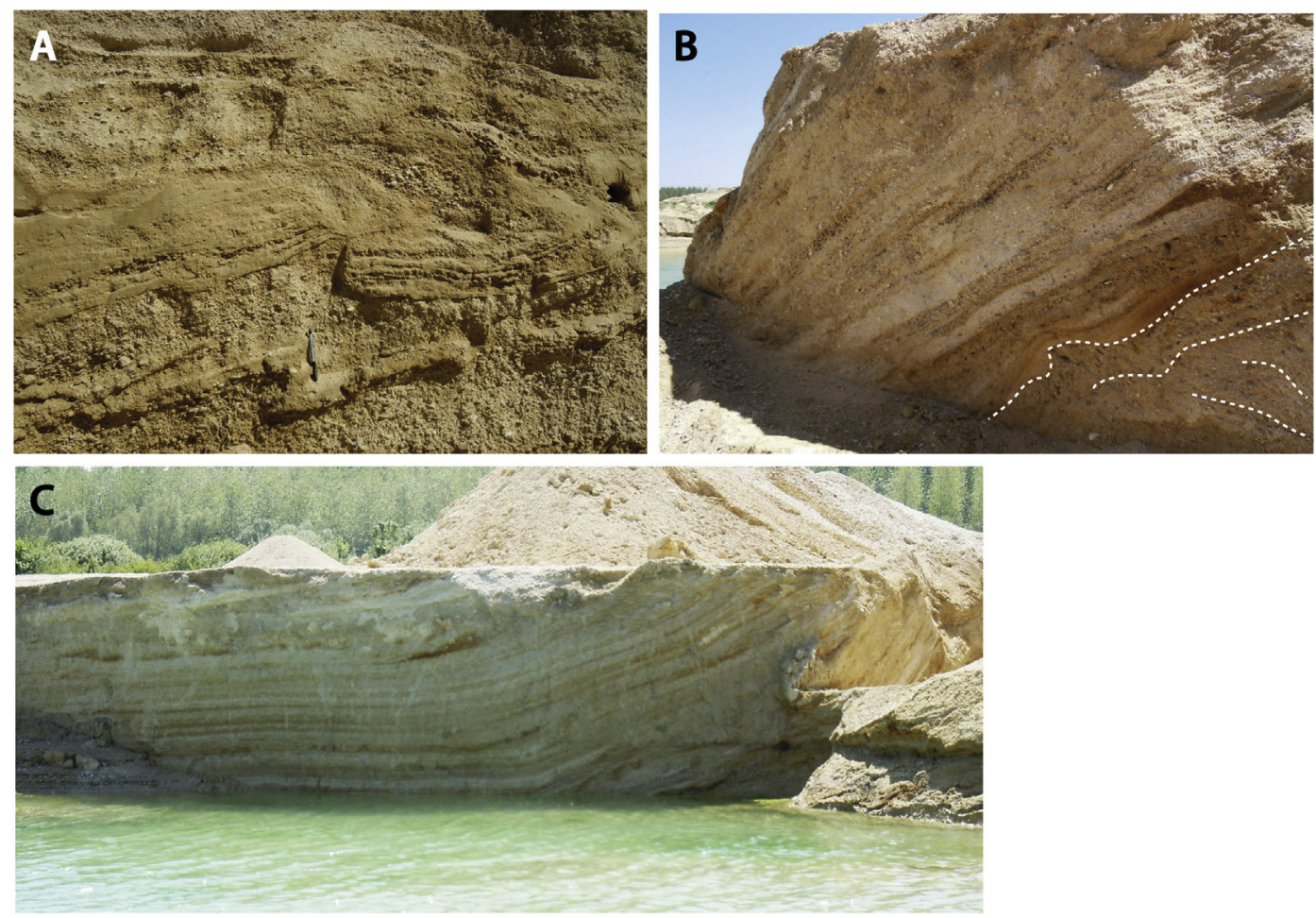

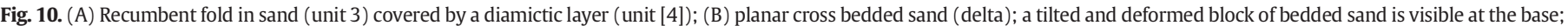

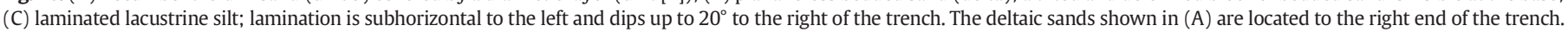

\subsubsection{Chronological data}

Radiocarbon dating of lake silts collected at the bottom of the main trench (Fig. 6) provided an age of 20,320 \pm 70 BP (Beta-470,451), i.e., after calibration (Intcal13 calibration curve, Reimer et al., 2013) be-

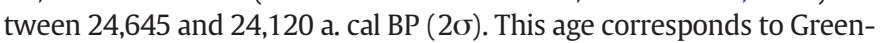
land stadial GS-3 (Rasmussen et al., 2014), one of the coldest periods of the Last Glacial (Hughes and Gibbard, 2015).

The OSL dating of unit [3] sands (location in Fig. 6) was also carried out from which an age of $16.6 \pm 0.9 \mathrm{ka}$ (Shfd 17,101) was obtained. This places the late phase of fluvial deposition within Greenland Stadial GS2.1a.

\subsubsection{Interpretation}

The site of Marcilly-sur-Seine shows lake deposits resting on the lower terrace (Fy) of the Seine River. The low organic content of the silts suggests that the banks were poorly vegetated and that the biological productivity in the lake was weak. Lamination preservation also indicates a near absence of bioturbation on the lake bottom. Because the lake was shallow, these features indicate an environment unfavourable to biological activity, probably a periglacial context in agreement with the numerical ages obtained. In such a context, the hypothesis of a thermokarst origin can be proposed. It is supported by the following arguments:

- According to the widely accepted scheme for northern Europe, the rivers adopted a braided pattern during the Last Glacial
(Antoine et al., 2003; Briant et al., 2005; Vandenberghe, 2008). The accumulation of fine-grained particles in abandoned channels is typically reduced (Miall, 1996), and the formation of thick lake deposits seems unlikely in this kind of fluvial environment.

- Lake silts formed after a phase of ice wedge degradation associated with sediment subsidence and fracturing. The development of shallow thermokarst lakes (typically 1-5 m; Hinkel et al., 2012) caused by the melting of ice wedge networks is a common process in permafrost-affected floodplains of modern Arctic milieus. Drainage occurs as a result of erosion of the lake margin by fluvial channels, or because of the decay of ice wedge polygons in adjacent land (Mackay, 1988; Jones and Arp, 2015), or else because of permafrost thaw under the lake (Yoshikawa and Hinzman, 2003). The presence of ice wedge pseudomorphs in the Fy alluvium is attested in many sites in the study area (Michel, 1975; Fig. 13). The mound-like topography observed on the edge of the Fy terrace (Fig. 4) can also be interpreted as remnants of degraded ice wedge polygons (badland thermokarst reliefs; French, 2007; Kokelj and Jorgenson, 2013; Steedman et al., 2016), and the shallow sinuous valleys between these reliefs are likely to be meltwater channels (Fortier et al., 2007).

- Fluvial channels built small deltas in the lake. The lake centre collapsed and the laminated deposits were deformed. Tilting of the deltas during their edification indicates that subsidence may have

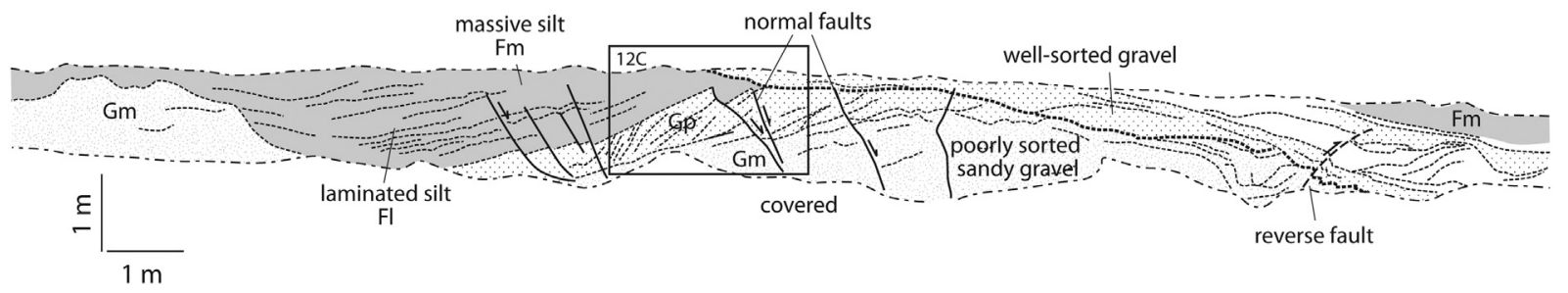

Fig. 11. Schematic stratigraphy of trench 2, Marcilly-sur-Seine. Same lithofacies codes as in Fig. 6. 

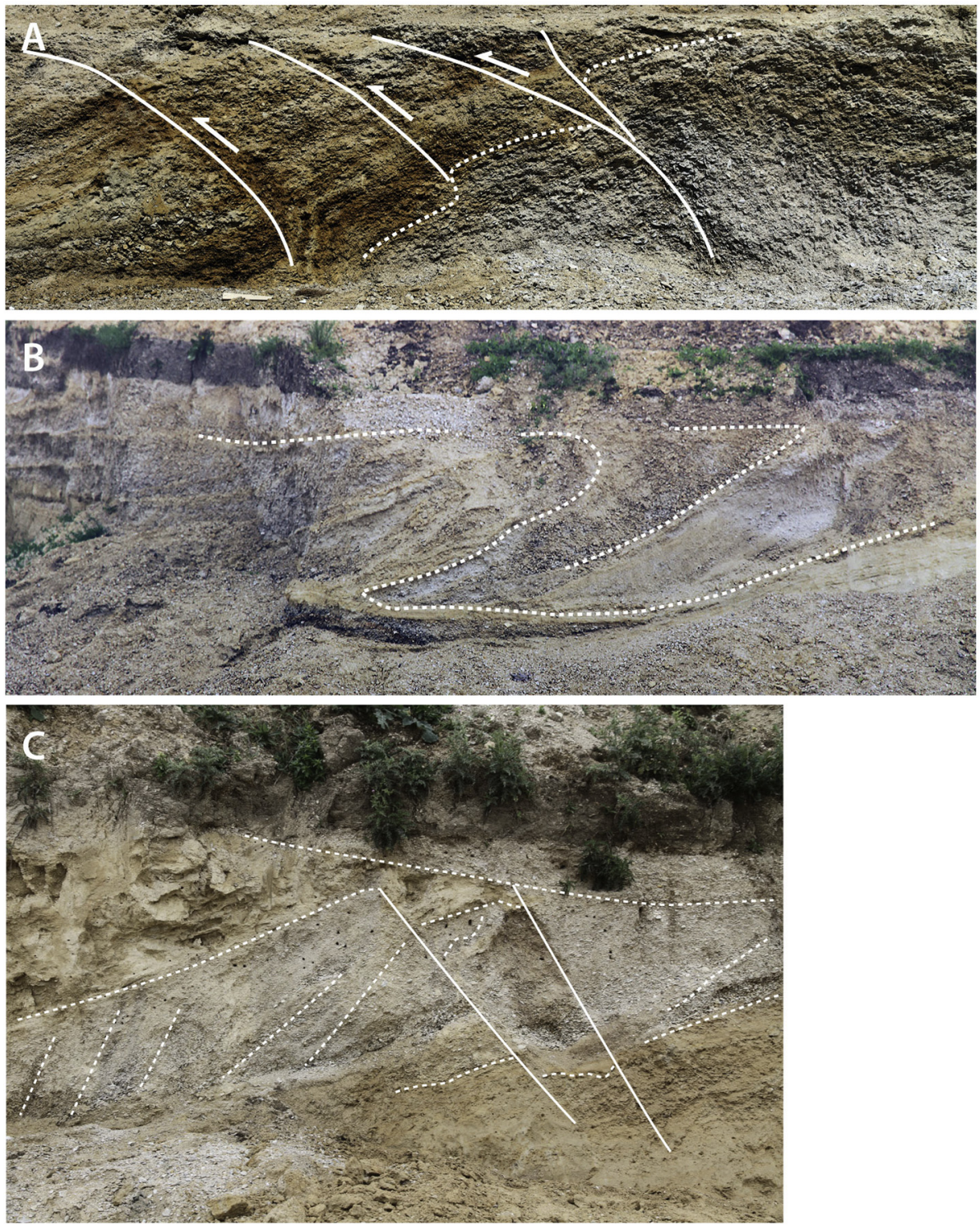

Fig. 12. (A) Reverse faults in alluvial sand and gravel; (B) overturned fold in bedded lacustrine sand and silt; (C) normal faults in deltaic sand. The location of (C) is indicated in Fig. 11. All photos are from P. Benoit.

been partly synsedimentary. This would result from progressive permafrost melting during widening of the thermokarst lake (Morgenstern et al., 2013).
The large recumbent folds are original structures rarely reported in the literature. Related structures have been described by Pissart (2000a, 2000b) in ramparts surrounding Younger Dryas lithalsa scars
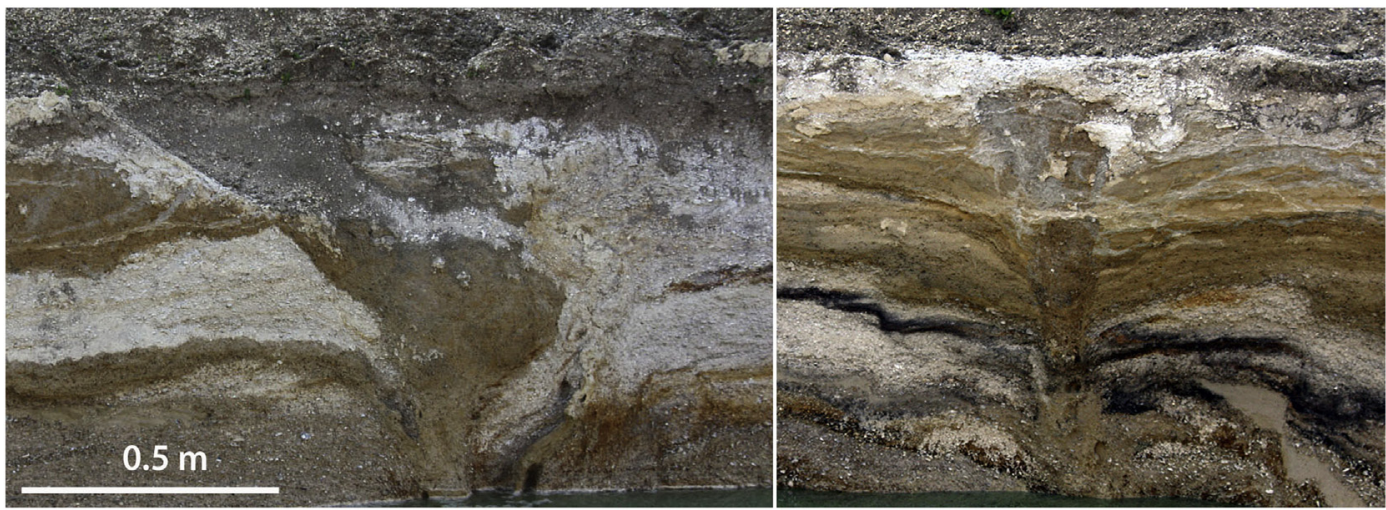

Fig. 13. Ice wedge pseudomorphs in Fy terrace, Sauvage quarry (photos P. Benoit). 
in Belgium. According to Pissart et al. (2011), the growth of segregation ice mounds in the context of discontinuous permafrost would cause vertical and lateral thrusting of the surrounding sediments. The circular ramparts that remain after ice melting originate from the combined action of lateral thrusting during lithalsa growth and of active layer slumping on the hillside. Trenches in the ramparts show folds induced by slumping and often normal and reverse faults. Mound collapse during thaw causes subsidence of the deformed sediments, and the hinge of the folds then becomes subhorizontal. In the context of Marcillysur-Seine, the growth of ice-cored mounds during periods of permafrost development appears highly probable and would have been responsible by part for the formation of pools. According to Wolfe et al. (2014) in Canada, the lithalsas develop mainly in fine-grained deposits favourable to ice segregation, especially in glaciomarine or glaciolacustrine clayey silt deposits in wet lowlands. They reach 1 to $10 \mathrm{~m}$ in height and have a rounded or elongated shape (lithalsa plateaus and ridges). This type of context appears similar to that inferred at Marcilly-sur-Seine.

Fig. 14 depicts the main sedimentary phases identified in Marcillysur-Seine. Ice wedge formation predates $24 \mathrm{ka}$ cal BP and may correspond to the main phases of ground ice development (31-25 ka) as identified from the loess sections in northern France (Antoine et al., 2014; Bertran et al., 2014).

\subsection{Gourgançon}

\subsubsection{Geomorphological setting}

Gourgançon $\left(48.6840^{\circ} \mathrm{N}, 4.0380^{\circ} \mathrm{E}\right)$ corresponds to an old quarry in the Fy alluvial terrace of the Maurienne River, a small tributary of the Aube River. The river watershed is entirely located in Cretaceous terrains, and therefore, the fluvial deposits are mostly calcareous. The local substrate is composed of Santonian (c4) and Campanian (c5) chalk, which forms hilly relief up to $50 \mathrm{~m}$ above the valley (Fig. 15). The chalk is affected by faults near the site (Baize et al., 2007). The discontinuous loess cover and the underlying fragmented chalk are frequently affected by cryoturbation, which forms soil stripes on slopes. The IGN aerial photographs make it possible to identify soil stripes in many fields surrounding the study site, particularly in areas where the Campanian substrate outcrops (Fig. 16). Gourgançon has been the subject of previous publications (Baize et al., 2007; Benoit et al., 2013; Van Vliet-Lanoë et al., 2016), and divergent interpretations were proposed to explain the origin of the deformations.

\subsubsection{Stratigraphy}

The stratigraphy comprises the following units, from the bottom to the top (Fig. 17):

[1] Poorly stratified chalk gravel (Gm), mostly exposed in the SW part of the quarry with a maximum thickness of $3 \mathrm{~m}$. This unit is interpreted as alluvium.

[2] Dominantly horizontally bedded sand and small gravel (Sh) (Fig. 18A, B). Lenses with planar cross bedding (Sp, current ripples) or massive lenses ( $\mathrm{Sm}$, probably related to sedimentary mass flows) are also visible. This unit is 1 to $3 \mathrm{~m}$ thick and mostly develops at both ends of the outcrop.

[3], [4] Laminated silt and fine sand (Fh) (Fig. 18C, D) showing by place a prismatic structure. These units develop in the central part of the outcrop where they reach almost $3 \mathrm{~m}$ thick. Lamination is mostly horizontal but shows a significant dip in the NE part of the cross section. In this area, the lower unit [3] has a strong dip $\left(16-20^{\circ}\right)$ and is affected by brittle deformation. The upper unit [4] rests unconformably on unit [3] and dips at a smaller angle $\left(5-7^{\circ}\right)$. Bedding at the top of the lower unit is distorted and evanescent. Deformation is interpreted as resulting from slumping of the silts.

[5] Up to $1 \mathrm{~m}$ thick sand and small gravel with planar cross-bedding (Sp) passing laterally to unit [4] (Fig. 18C).

Units [2] to [5] are interpreted as lake deposits similar to those observed at Marcilly-sur-Seine. According to Van Vliet-Lanoë et al.
(2016), the prismatic structure would reflect the development of reticulate ice in the silts. The SW zone of the outcrop, where the silt units are lacking, probably represents a delta fed by inputs coming from the nearby hillslope or, possibly, by alluvial deposits from the Maurienne River. A second delta, later covered by laminated silts, is also visible in the NE part of the section. The foresets [5] reflect delta progradation toward the SW during the final evolution of the lake.

\subsubsection{Deformation}

Widespread deformation affects the deposits. Two events can be identified: the first located to the NE is synsedimentary; the second to the SW is postsedimentary. The structures are organised in a similar way and comprise:

- A network of symmetric bell-shaped reverse faults (Figs. 17, 18A). In the SW part of the cross section, which is the most legible, the fault structure is located just above a depression in alluvial deposits, which have been injected by a large body of unstratified, upwardfining sand. The injection has a globular shape with protrusions interpreted as dykes.

- A network of conjugate normal faults developed laterally to the reverse faults (Fig. 18B).

The first generation of faults developed between two phases of lake sedimentation (Fig. 19) and followed a bulging of the deposits, which caused their slump. The heaved deposits were truncated, and the later lacustrine unit was deposited unconformably on the former. The second faulting event to the SW intersects the whole sequence and has therefore developed at the very end of lake infilling.

\subsubsection{Chronological data}

Because of the lack of organic material and the calcareous composition of the deposits, the chronological framework available for this section is limited. The OSL dating of sand from unit [2] was previously tried by CIRAM (CIRAM, 2014), and enough quartz grains were retrieved. The sample gave an age of $13.57 \pm 0.56 \mathrm{ka}$, contemporaneous with the Bölling-Alleröd interstadial (Greenland Interstadial (GI) 1; Rasmussen et al., 2014) at the end of the Last Glacial. However, since this age reflects the last exposure to light of the quartz grains, i.e., the time of burial, this OSL age would imply that deposition of the overlying sediments, including the lake deposits, would have taken place during the Lateglacial or the Holocene. The lithofacies, however, is not compatible with such an age when compared to other regional alluvial records (Pastre et al., 2001; Antoine et al., 2003), and deposition in an earlier phase of the Last Glacial must be favoured. Incorrect $\gamma$-ray dose rate assessment because of sediment heterogeneity could lead to age underestimation by a few millennia. The similarity of the sedimentary sequence with that of Marcilly-sur-Seine also strongly suggests that lake sedimentation occurred during the Last Glacial.

\subsubsection{Interpretation}

As in Marcilly-sur-Seine, the sedimentary sequence shows lake deposits overlying coarse-grained alluvium. Deposition took place in a periglacial context and reticulate ice developed in shallow lake sediments. Consequently, thermokarst may be proposed as the most plausible factor for lake formation.

Brittle deformation affected the lacustrine units. The deformation pattern, which associates a network of bell-shaped reverse faults and normal faults, has already been described from laboratory experiments aimed at reproducing the subsidence of a block under a soft cover (Sanford, 1959) or the formation of a caldera above a magmatic chamber (Roche et al., 2001; Walter and Troll, 2001; Geyer et al., 2006; Coumans and Stix, 2016). In these experiments, bell-shaped fractures form in granular material above the chamber, and annular tension cracks (normal faults) starting from the surface accommodate the collapse laterally. Further development of the fractures up to the surface 
ice wedge polygons
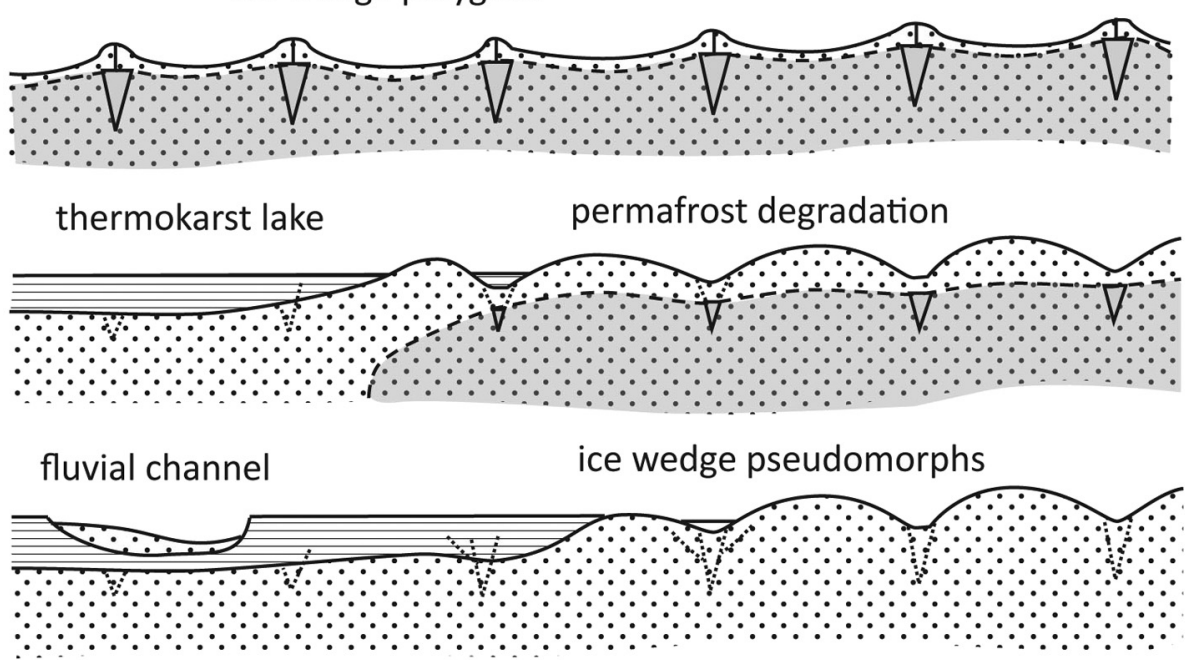

lithalsa

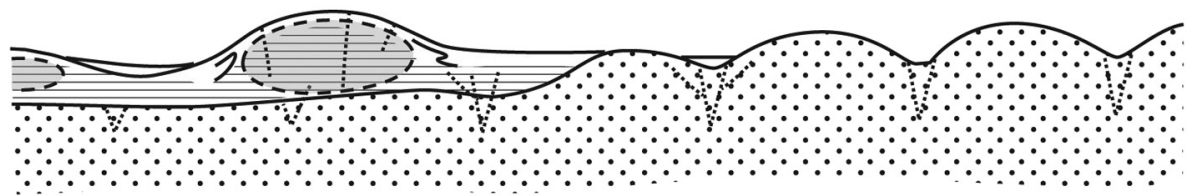

thermokarst lake
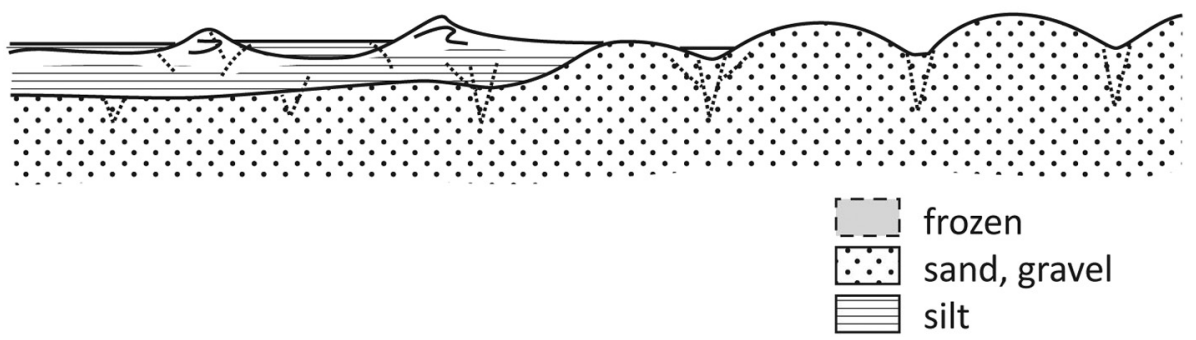

Fig. 14. Schematic reconstruction of the main sedimentary phases recorded at Marcilly-sur-Seine.

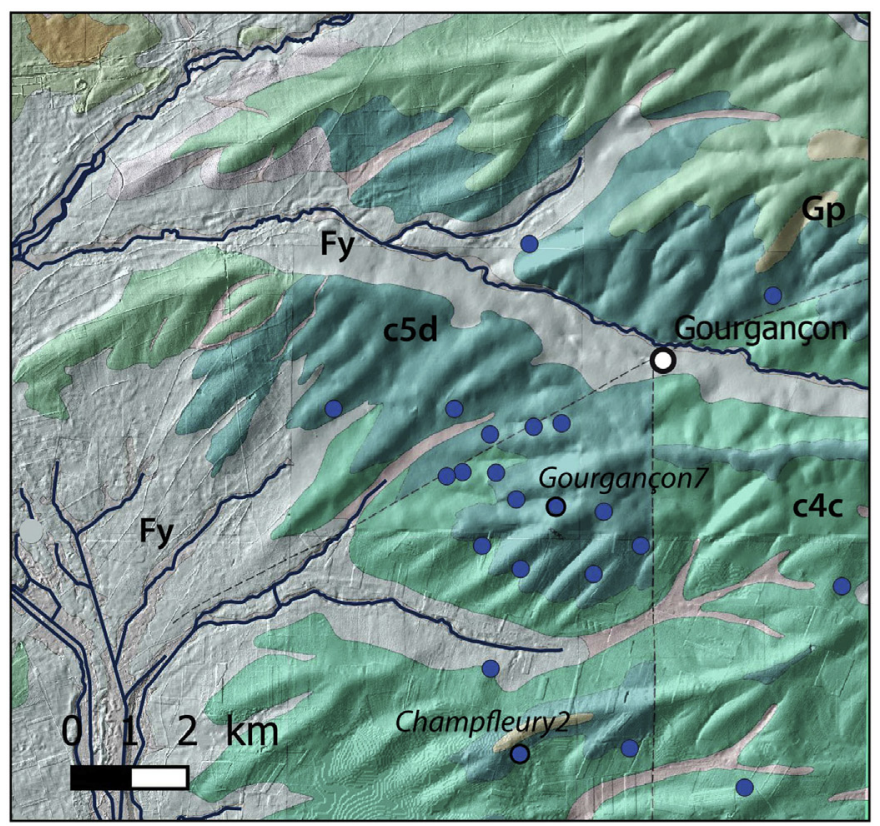



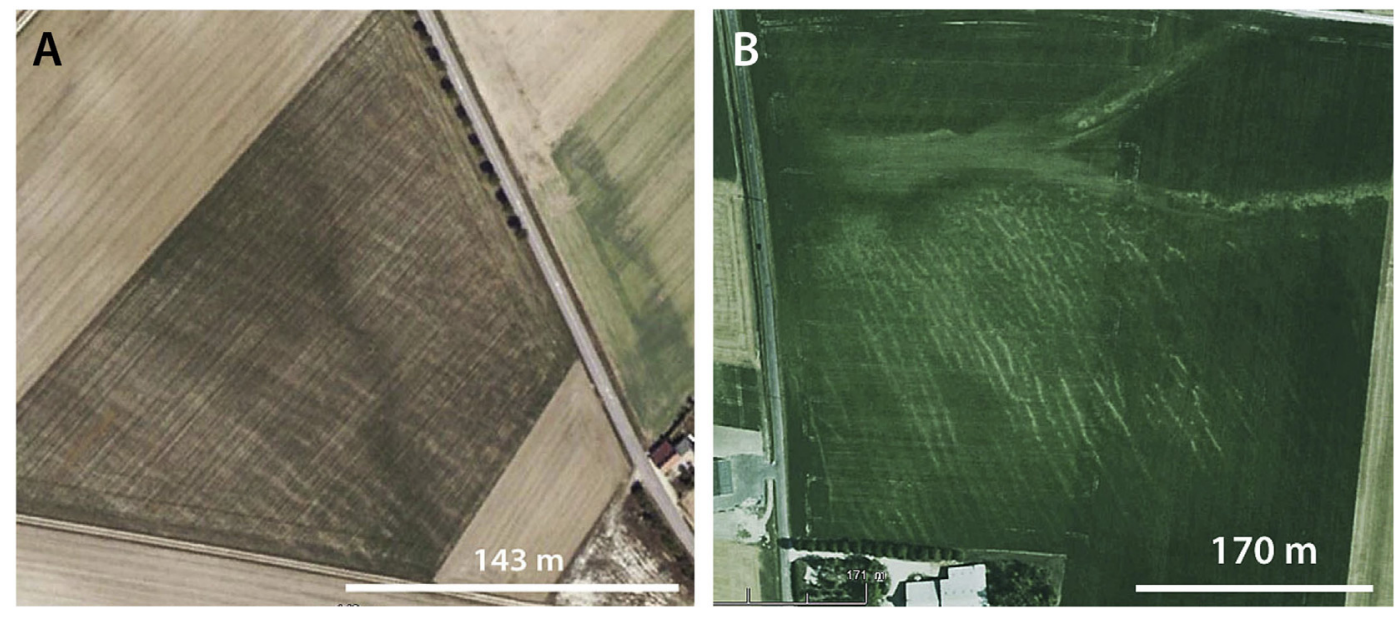

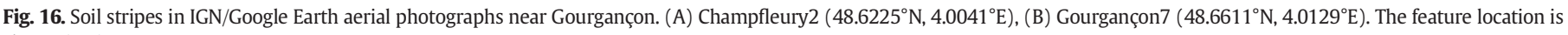
shown in Fig. 14.

is accompanied by downward movement of the lower blocks toward the cavity (reverse faulting) (Fig. 19A). Successive fractures are created as the cavity collapses and fills. In the case of uneven vertical stress due to surface reliefs, Coumans and Stix (2016) showed that fracturing may develop asymmetrically above the cavity, and a system of conjugate normal faults forms preferentially in the highest side (Fig. 20B).

The fault distribution at Gourgançon shows that two zones of collapse developed: one to the NE between two phases of lacustrine sedimentation; the other to the SW during a final phase of lake filling. The SW structure is centred above a sand injection, showing that high interstitial water pressure occurred leading to hydraulic fracturing and sand fluidization (Ross et al., 2011b). The association between injection and faulting of the overlying sediments strongly suggests that the two phenomena are genetically linked. Therefore, ground subsidence following the collapse of a cavity created by the emptying of a liquefied deep sand layer seems to be the most plausible factor at the origin of faulting.

Excess water pressures may be related to different contexts. In nonperiglacial environments, interstitial water pressures higher than hydrostatic hardly develop in freely drained coarse-grained materials unless an external stress is applied. In particular, liquefaction of watersaturated sand, hydraulic fracturing, and fluidization have been reported as a consequence of earthquakes (Youd, 1973; Audemard and de Santis, 1991; Obermeier et al., 2005; Thakkar et al., 2012). In periglacial environments, excess water pressure may occur either because of permafrost aggradation at the expense of an unfrozen ground pocket (talik), e.g., during refreezing of sediments in a drained lake in the context of continuous permafrost (closed system), or through gravity-induced water flow in a thawed layer beneath or within the frozen ground (open system) (Mackay, 1986, 1998; Yoshikawa, 1993). Hydraulic fracturing and water injection followed by its transformation into ice gives rise to massive ice sills overlain by a few decimetre-thick sedimentary cover (pingos, seasonal frost blisters). These can reach several meters in height. Continuous permafrost (and, therefore, the formation of closed system pingos) during the Last Glacial is unlikely in the Paris Basin (Andrieux et al., 2016a). However, the palaeoclimatic (widespread discontinuous permafrost) and geomorphological contexts (alluvium at the foot of a slope) was favourable to the development of open system pingos or frost blisters (e.g., Pollard and Van Everdingen, 1992; Yoshikawa, 1993; Worsley and Gurney, 1996). In the examples investigated in modern Arctic environments, ground water was confined between the permafrost and the frozen part of the active layer in an alluvial fan or plain. Excess water pressure resulted from gravity flow between the feeder zone and the site. The growth of ice mounds in a fluvial channel led to its abandonment by the river (Worsley and Gurney, 1996).

In the NE fault zone, no injection structure was observed and the mechanism responsible for collapse and fracturing is less obvious. Tilting of laminated silts, indicative of bulging, followed by slumping provide clear evidence that a mound formed laterally in the lacustrine deposits. This mound developed probably after lake drainage and exposition of the sediments to frost, leading to the growth of segregation ice (lithalsa) or injection ice (or both as is the case for many modern ice mounds according to Harris and Ross, 2007). The lack of obvious injection features may be result from the inappropriate location of the cross section with respect to the structure or from the absence of a sand layer prone to liquefaction at depth. Active layer slumping suitably explains tilting of lacustrine silts [unit 3], soft-sediment deformation observed at the top of this unit, and truncation. Subsequent collapse and fracturing caused by ice melting was followed by resumption of lake sedimentation.

\subsection{Other potential thermokarst structures in alluvial context in the Paris Basin}

Cross sections in alluvial deposits from the Last Glacial potentially hosting thermokarst structures (except for ice wedge pseudomorphs) are rare. To overcome this difficulty, other indices have been sought to

SW

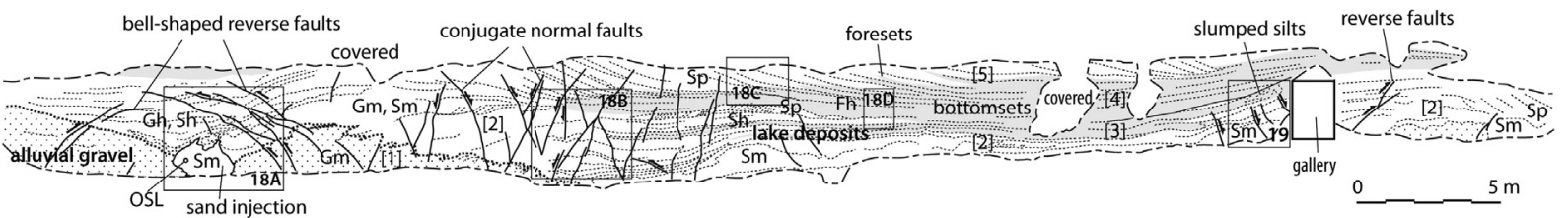

Fig. 17. Schematic stratigraphy of Gourgançon quarry front. Same lithofacies codes as in Fig. 6 . The rectangles indicate the location of the photographs shown in Figs. 18 and 19. 

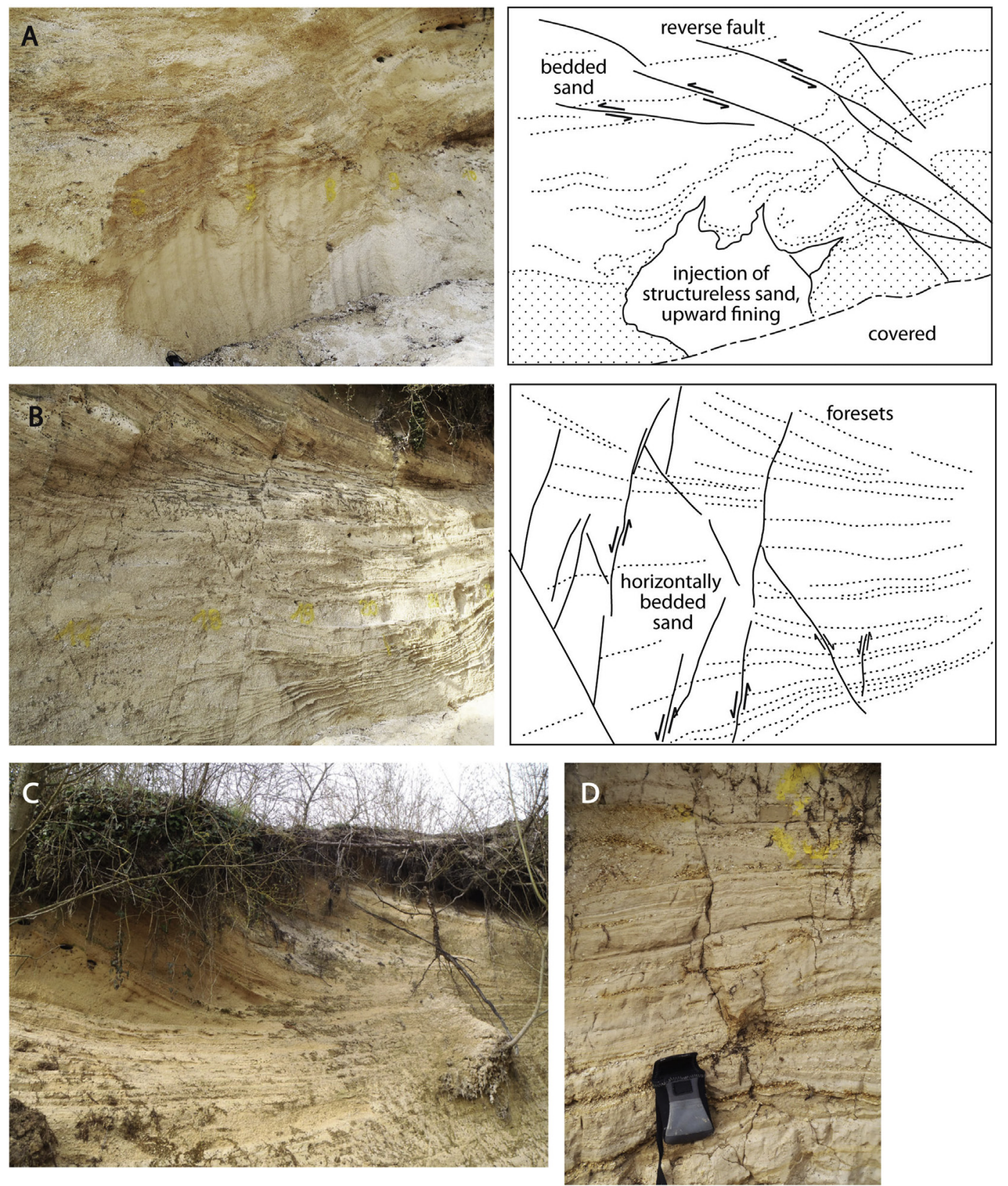

Fig. 18. Close-up view of (A) reverse faults and sand injection in bedded sand (unit 2); (B) conjugate normal faults in bedded sand; (C) foresets (unit 5); (D) lacustrine silts (unit 4).

try mapping the areas affected by thermokarst. These indices are based on the detailed topographical data available from the 5-m DEM (IGN) and on the aerial photographs accessible in Google Earth. The thermokarst features at Marcilly-sur-Seine are associated with a pitted or undulating topography and a spotted pattern on aerial photographs. This pattern typifies the whole Fy terrace near the Seine-Aube confluence (cf. Van Vliet-Lanoë et al., 2016). Dark spots correspond to finegrained wet (lacustrine) deposits, while light spots indicate that coarser well-drained alluvial materials are exposed. Similar features have, therefore, been sought in other areas of the Paris Basin. If possible, the presence of potential lake deposits has been verified through the borehole data stored in the BSS (BRGM).

The identified sites are plotted in Fig. 21. All are located in upper Cretaceous terrains north of latitude $48^{\circ} \mathrm{N}$, in an area with abundant ice wedge pseudomorphs (Andrieux et al., 2016a). These features are sometimes associated with other periglacial structures, such as polygons in nearby alluvial deposits (Fig. 22), or soil stripes on slopes.
In some sites, available boreholes show fine-grained light-coloured levels, generally described as 'grey clays' (Fig. 23). These deposits, 0.5 to $3 \mathrm{~m}$ thick, appear most often at the top of the alluvial sequence, or more rarely are interstratified in alluvial sand and gravel. They contrast with Holocene channel fillings, which usually have a dark colour because of their high content in organic matter and are similar to the lacustrine silts observed at Marcilly-sur-Seine. Michel (1967) also describes 'marly silts' associated with depressions thought to be of thermokarst origin in the Fy terrace in an area located near Villierssur-Seine, 20 to $40 \mathrm{~km}$ west of Marcilly-sur-Seine.

\section{Discussion}

\subsection{Origin of the brittle deformation}

The sites of Marcilly-sur-Seine and Gourgançon show that thermokarst lakes developed during the Last Glacial in alluvial deposits 

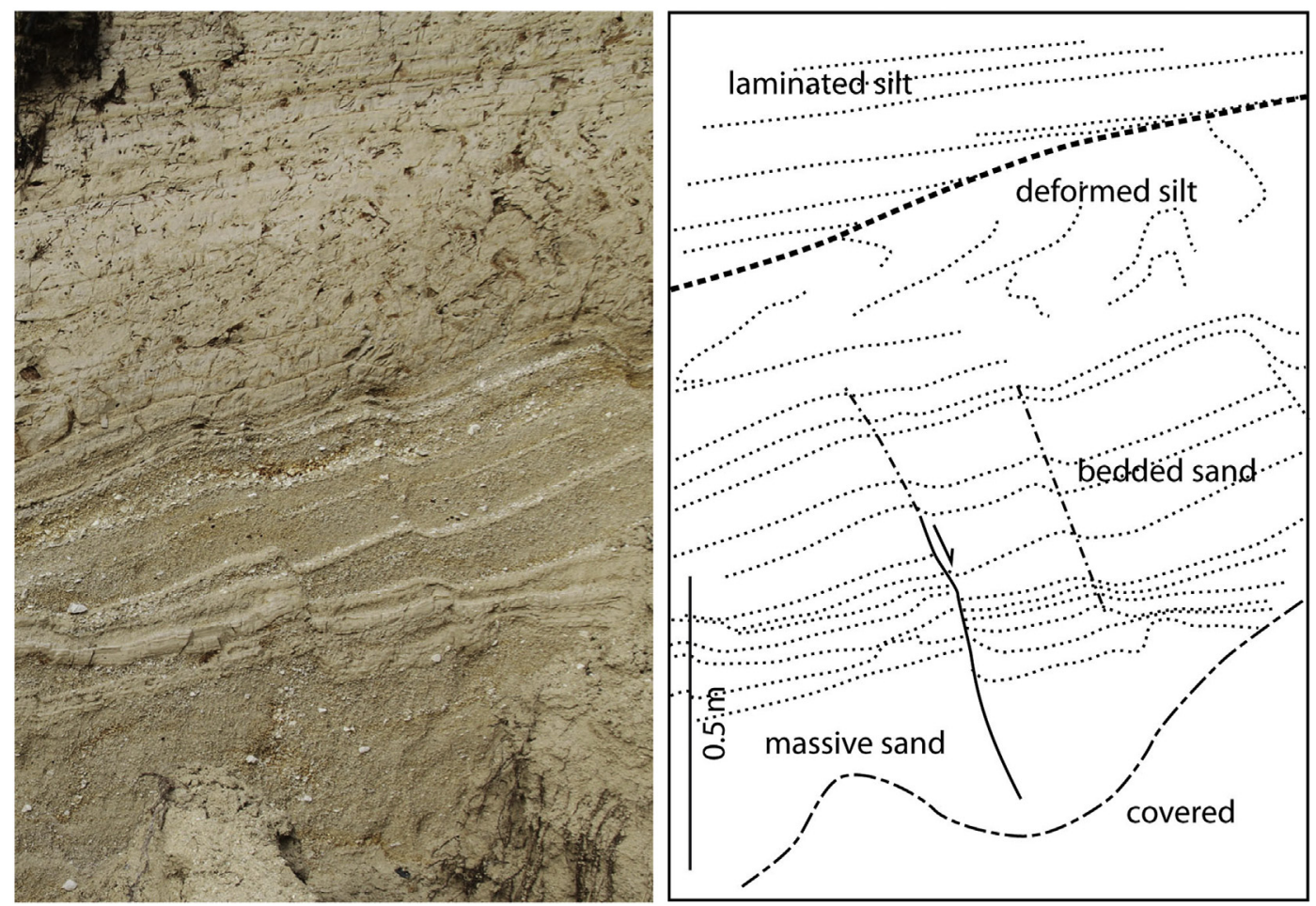

Fig. 19. From bottom to top, faulted sand (unit 2), slumped silt (unit 3), slightly dipping laminated silt (unit 3) lying unconformably over unit [2].

in the Paris Basin. In the first site, thermokarst is clearly associated with the melting of an ice wedge network. At least two phases of thermokarst development followed by a phase of lake drainage, alluvial deposition, and segregation ice growth (platy structure) can be identified. According to some authors (French, 2007), such an evolution can occur autocyclically without any climate forcing. When water does not freeze up to the lake bottom in winter, the underlying permafrost degrades (formation of a talik beneath the lake) either partially or totally in areas of thin discontinuous permafrost (Yoshikawa and Hinzman, 2003). Within the frame of the French Pleistocene, the succession of stadials and interstadials probably played a major role in permafrost evolution (Antoine et al., 2014; Bertran et al., 2014) and may explain the cyclic development of thermokarst in the floodplain. The finegrained lacustrine deposits have themselves promoted the growth of segregation ice mounds. These have resulted in significant deformation of the sediments. Ductile deformation developed mainly caused by
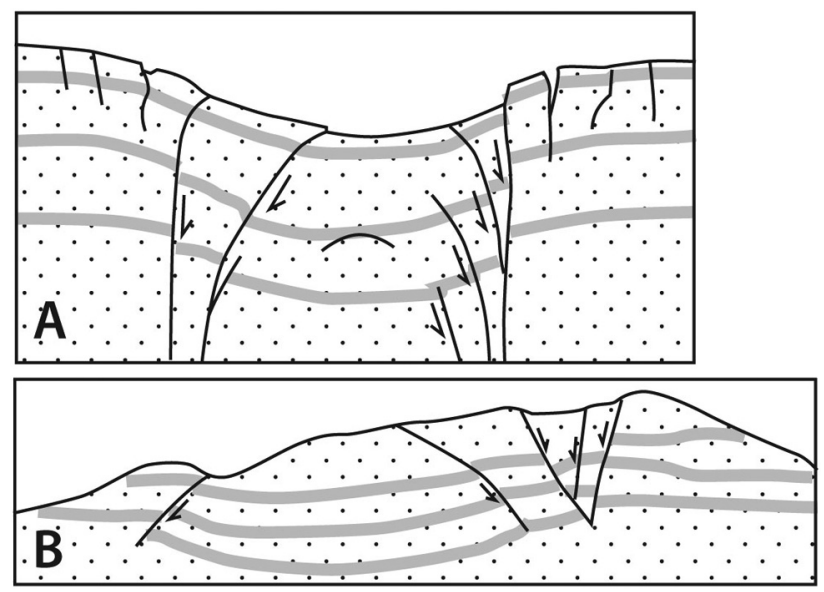

Fig. 20. (A) Experimental bell-shaped faults developed above a cavity in a sand box, from Geyer et al. (2006); (B) asymmetrical collapse under a sloping surface, from Coumans and Stix (2016). slumping of the lifted active layer on hillsides. The associated features are intersected by pervasive brittle deformation.

According to the contextual analysis, a periglacial origin is the most parsimonious hypothesis to explain fracturing. The faults are attributed to sediment settlement after melting of ice wedges and segregation or injection ice bodies. Because of the scarcity of natural cross sections, faulting has been rarely reported from modern permafrost regions. Mention of steeply dipping, ice-filled reverse faults has been made by Calmels et al. (2008) from cores in a lithalsa from northern Quebec (Canada). Large subvertical ice-filled fractures were also observed by Wünnemann et al. (2008) in a lithalsa section from India. According to Calmels et al. (2008), the faults would have developed during the growth of ice lenses following permafrost aggradation. They would have been initiated by cryodessiccation cracks, and the offset would have resulted from the differential growth of ice lenses. Normal and reverse faults have been described in Pleistocene pingo and lithalsa scars by Kasse and Bohncke (1992) and Pissart (2000a, 2000b). In these cases, thaw settlement was thought to be the main factor involved in faulting. Thaw settlement-induced normal faulting in the sandy host material of Pleistocene and Holocene ice wedge pseudomorphs is also commonly reported (e.g., Murton, 2013).

The origin of brittle deformation frequently observed in the Pleistocene alluvium of the Paris Basin has been strongly debated in the literature and different hypotheses have been proposed. Coulon (1994), Benoit and Grisoni (1995) and Benoit et al. (2013) favoured a seismic hypothesis. Fracturing was thought to reflect the propagation of deepseated faults through superficial sediments during earthquakes. Sand injections would have been triggered by local liquefaction of the sediment caused by seismic vibrations.

Baize et al. (2007) considered the hypothesis of dissolution of the underlying limestone (karst formation) to be the most likely to explain the faults observed at Gourgançon. They reject a seismic hypothesis, mainly because of (i) the low regional seismicity both for the recent and the historical periods; (ii) the large cumulated offset of the faults $(>1 \mathrm{~m})$, which would imply a high magnitude earthquake unlikely to occur in the geodynamical context of the Paris Basin; and (iii) the mismatch between movements recorded by the faults affecting the 


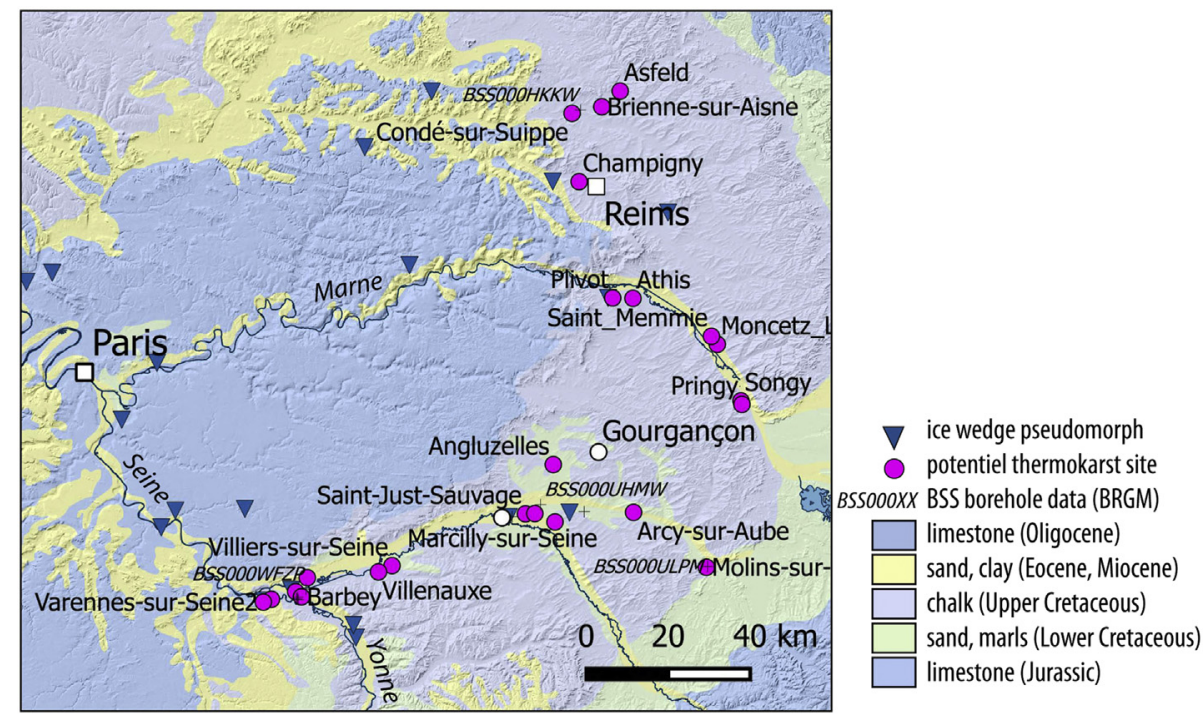

Fig. 21. Location of potential thermokarst sites and borehole showing supposed lake deposits in the Paris Basin. Ice wedge pseudomorphs are from Andrieux et al. (2016a, 2016b).

Pleistocene deposits and those in the Mesozoic chalk substrate. Since then, further cleaning of the quarry front highlighted the symmetrical nature of the reverse fault network, which fits well with the collapse of sediments over a cavity. Some arguments weaken the karst hypothesis, however. These are (i) chalk karstification is generally limited, although not entirely absent (Rodet, 2013); (ii) a faulting phase occurred between two phases of lacustrine silt deposition; the glacial periods were, however, not favourable to dissolution because the production of $\mathrm{CO}_{2}$ in soils by living organisms remained low (e.g., Ford, 1993); the deposits are carbonate-rich and the ground water was probably saturated with respect to calcite; (iii) the strong local dip of silt layers and the presence of an erosional surface within the deposits show that these have been affected by a phase of bulging, which is hardly explainable within the frame of the karst hypothesis; and (iv) karst does not account for the association between fracturing and the injection of fluidised sand in the centre of the fault structure.

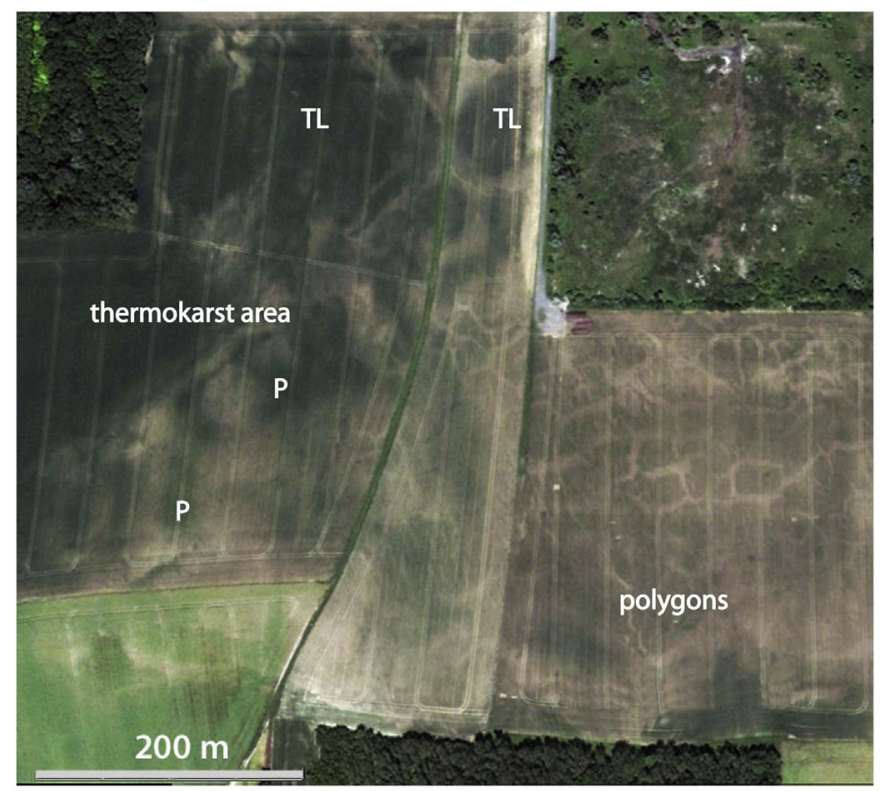

Fig. 22. Aerial view of Varennes-sur-Seine site (IGN/Google earth) showing transition between former ice wedge polygons and depressions of various shapes probably of thermokarst origin (P: pits at the intersection of ice wedges, TL: thermokarst lakes).

The scenario proposed by Van Vliet-Lanoë et al. (2016) favoured a periglacial origin for the faults. Accordingly, fracturing would be caused by sliding of the deposits into a depression left by ice melting, possibly from a lithalsa. The movement would have occurred over a sliding plane formed at the base of the lacustrine silts, and the arched shape of the faults would be related to later deformation by frost-creep.

\section{BSSOOOWFPH}

0

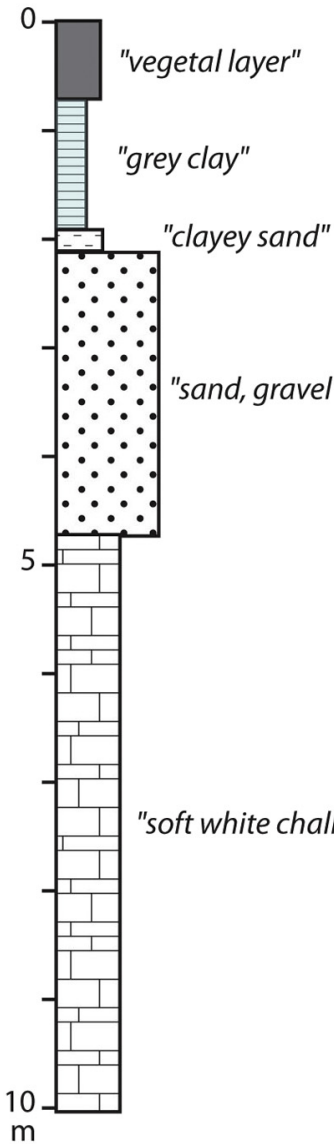

Fig. 23. Schematic stratigraphy of two boreholes showing potential lake deposits, from BSS (BRGM), and interpretation. BSSO0OWFPH - Barbey, BSSO00UHFB - Saint-Just-Sauvage.

\section{BSSO0OUHFB}

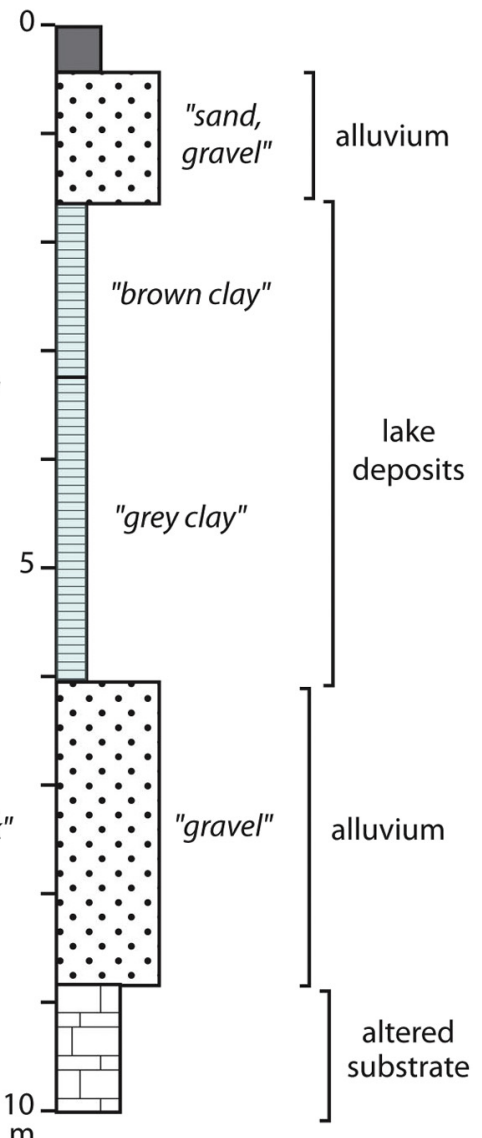

( ther 
However, this mechanism does not take into account the symmetric development of the faults, which excludes horizontal spreading as the main process but is in agreement with the model of collapse above a cavity. The sand injection was interpreted by Van Vliet-Lanoë et al. (2016) as slow soft-sediment deformation following ice melting. Such a hypothesis seems equally unlikely, as it does not account for the isolated nature of the structure, which contrasts with classical load cast observed in periglacial contexts (Vandenberghe, 1992, 2013; Bertran et al., 2017), and for the lack of evidence for slow deformation of watersaturated material such as bedding deformed parallel to the structure outlines. In contrast, the sand body shows a lack of bedding, compatible with sand fluidization, an upward fining that testifies to settling of the particles from a suspension, and protrusions, which indicate hydraulic fracturing of the host sediment. These features are thought to be more indicative of sudden intrusion of water-suspended sand through the overlying layers than of slow sediment deformation upon thawing.

\subsection{Pattern and distribution of thermokarst structures}

Although the formation of lakes in connection with the melting of ice wedges in low-lying areas is well documented from today's Arctic environments, no similar structure has been described so far in Europe except for a few sites from the Netherlands and eastern Germany (Van Huissteden and Kasse, 2001; Bohncke et al., 2008). In those sites, the lake infillings comprise organic silt layers (gyttja) a few decimetres thick and alluvial and aeolian sand. According to Bohncke et al. (2008), the basal lake deposits are affected by involutions that would have formed during permafrost degradation. Contrary to Marcilly-surSeine, the overlying lacustrine units do not exhibit any significant deformation, possibly because of their low thickness and of rapid burial during the subsequent stadial.

If the hypothesis of lithalsa formation at Marcilly-sur-Seine is correct, we can note that they did not generate ramparts clearly identifiable in the field and from the 5-m DEM. In addition, the pattern in aerial photography does not reveal any obvious circular structure as initially expected, but mostly irregular dark and light-coloured spots. At Gourgançon, the low quality of the DEM and the disturbances caused by quarrying do not make it possible to identify specific reliefs. Circular ramparts (sometimes elongated along slopes) are considered the best criterion for identifying scars of ice-cored mounds, and many examples have been reported from northern Europe (Watson, 1971; Pissart, 1983, 2000a, 2000b; Kasse and Bohncke, 1992; Ballantyne and Harris, 1994; Ross et al., 2011a). The few dated examples show, however, that these ramparted structures are quite recent, i.e., Younger Dryas (MIS 1) or very end of the Last Glacial (late MIS 2) (review in Pissart, 2000b). Erosion by a wide range of geomorphological processes (slumping, frost creep, overland flow, fluvial processes, deflation) may explain the faint reliefs still surrounding late MIS 2 scars (de Gans, 1988; Kasse and Bohncke, 1992) and the almost total disappearance of the ramparts in older scars. According to Pissart (2000a), the formation of lithalsa plateaus rather than isolated mounds may also be involved in the lack of circular structures left by ice melting. In Belgium, this author described areas with circular ramparts coexisting with areas of very confused topography, probably corresponding to the degradation of lithalsa plateaus. The association of lake deposits, evidence for a periglacial context, undulating or pitted topography, and abundant ductile and brittle deformation of the lacustrine layers is assumed here to be the most reliable criterion for the identification of Pleistocene lithalsas and lithalsa plateaus.

The alluvial sites potentially affected by thermokarst in the Paris Basin are distributed north of latitude $48^{\circ} \mathrm{N}$ in a zone that has yielded abundant ice wedge pseudomorphs in upper Cretaceous terrains. Unexpectedly, the search for similar structures in other regions of northern France was unsuccessful. In addition, laminated mineral lacustrine deposits on Pleistocene terraces have never been reported in the literature to our knowledge. The reason may be lithology. Lower
Cretaceous terrains (mostly composed of sand, clay, and marl) have delivered large amounts of fine-grained particles to the water courses that cross them. Fine particle accumulation in alluvial plains downstream gave birth to deposits highly susceptible to the formation of ice wedges and segregation ice. River incision in their lower course as a consequence of sea level lowering during the glacial was not favourable to broad sedimentation of fine-grained particles, and the almost exclusive supply of large elements (flint pebbles) by the upper Cretaceous chalk led to the deposition of dominantly coarse-grained alluvial material, in which ice growth was limited.

\section{Conclusion}

The Last Glacial fluvial sequences of the Seine and Maurienne rivers show laminated lacustrine deposits overlying alluvial sandy gravel. A thermokarst origin of the lakes is supported by abundant traces of ground ice, particularly ice wedge pseudomorphs beneath the lacustrine layers at Marcilly-sur-Seine, and synsedimentary deformation features caused by thaw settlement. These features include both brittle deformation (normal and reverse faults) resulting from ground subsidence caused by ice melting and ductile deformations caused by slumping of the sediments heaved by the growth of ice-cored mounds. These correspond to lithalsas (or lithalsa plateaus) at Marcilly-sur-Seine and open system pingos or lithalsas at Gourgançon. At least two generations of thermokarst are recorded in each quarry. They could reflect the Dansgaard-Oeschger millennial climate variability typical of the Last Glacial.

The structures studied in quarries are associated with a typical undulating topography and a spotted pattern in aerial photographs. The search for similar patterns in the Paris Basin indicates that many other potential thermokarst sites exist in the Last Glacial terrace (Fy) of rivers located north of $48^{\circ} \mathrm{N}$ when they cross the lower Cretaceous sands and marls. In some sites, the presence of organic-poor, fine-grained deposits presumably of lacustrine origin was confirmed by borehole data. The site distribution coincides in part with that already known for ice wedge pseudomorphs. The lack of identifiable thermokarst in large areas of northern France could be related to the coarser grain size of the alluvial deposits.

The discovery of lake deposits also opens up new possibilities for documenting the palaeoenvironments of the Last Glacial in the Paris Basin from pollen, insect remains, and other biomarkers, as they are still poorly known from continental records. This aspect, together with the precise dating of the deposits, should prompt further investigation.

\section{Acknowledgements}

This work has been funded by the SISMOGEL project involving Electricite De France, Inrap, and the universities of Bordeaux and Caen. We acknowledge all the people who contributed to the study, particularly P. Benoit, A. Queffelec, and J.C. Plaziat. The Société des Carrières de l'Est - Etablissement Morgagni, owner of the quarry, is also warmly acknowledged for its help in the field. Jef Vandenberghe and two anonymous reviewers are also thanked for their comments, which contributed to greatly improving the manuscript.

\section{References}

Adamiec, G., Aitken, M.J., 1998. Dose-rate conversion factors update. Ancient TL 16, 37-50.

Aitken, M.J., 1985. Thermoluminescence Dating. Academic Press, Orlando, Florida (359 p).

Andrieux, E., Bertran, P., Saito, K., 2016a. Spatial analysis of the French Pleistocene permafrost by a GIS database. Permafr. Periglac. Process. 27 (1), 17-30.

Andrieux, E., Bertran, P., Antoine, P., Deschodt, L., Lenoble, A., Coutard, S., Van Vliet-Lanoë, B., collaborators, 2016b. Database of Pleistocene periglacial features in France: description of the online version. Quaternaire 27 (4), 329-339.

Andrieux, E., Bateman, M., Bertran, P., 2018. The chronology of Late Pleistocene thermal contraction cracking derived from sand wedge OSL dating in central and southern France. Glob. Planet. Chang. 162. https://doi.org/10.1016/j.gloplacha.2018.01.012. 
Antoine, P., Rousseau, D.D., Lautridou, J.P., Hatté, C., 1999. Last interglacial-glacial climatic cycle in loess-palaeosol successions of North-Western France. Boreas 28, 551-563.

Antoine, P., Munaut, A.V., Limondin-Lozouet, N., Ponel, P., Dupéron, J., Dupéron, M., 2003. Response of the Selle river to climatic modifications during the Lateglacial and Early Holocene (Somme Basin, Northern France). Ouat. Sci. Rev. 22, 2061-2076.

Antoine, P., Moine, O., Hatté, C., 2013. Les processus thermokarstiques: marqueurs d'épisodes de réchauffement climatique rapides au cours du Dernier Glaciaire dans les séquences loessiques ouest-européennes. Oral Presentation, Chantier Arctique Français, 3-6 June 2013, Paris.

Antoine, P., Goval, E., Jamet, G., Coutard, S., Moine, O., Hérisson, D., Robert, V., 2014. Les séquences lœssiques Pléistocène supérieur d'Havrincourt (Pas-de-Calais, France): stratigraphie, paléoenvironnements, géochronologie et occupations paléolithiques. Quaternaire 25 (4), 321-368.

Audemard, F.A., de Santis, F., 1991. Survey of liquefaction structures induced by recent moderate earthquakes. Bull. Int. Assoc. Eng. Geol. 44, 5-16.

Baize, S., Coulon, M., Hibsch, C., Cushing, M., Lemeille, F., Hamard, E., 2007. Non-tectonic deformation of Pleistocene sediments in the eastern Paris basin, France. Bull. Soc. Geol. Fr. 178 (5), 367-381.

Ballantyne, C.K., Harris, C., 1994. The Periglaciation of Great Britain. Cambridge University Press, Cambridge.

Bateman, M.D., Catt, J.A., 1996. An absolute chronology for the raised beach deposits at Sewerby, E. Yorkshire, UK. J. Quat. Sci. 11, 389-395.

Becheler, P., 2014. L'origine tectono-karstique des lagunes de la région VillagrainsLandiras. L'écho des Faluns, Saucats 35-36, 11-17.

Benoit, P., Grisoni, J.-M., 1995. Tectoniques rissienne et fini-würmienne/holocène dans la basse terrasse de la rivière Aube (Longueville-sur-Aube), dans le sud-est du bassin de Paris, France. Bull. Inf. Géol. Bassin Paris 32, 7-11.

Benoit, P., Grisoni, J.M., Meghraoui, M., 2013. Quaternary faulting in the central Paris basin: evidence for coseismic rupture and liquefaction. Proceedings of the 4th International INQUA Meeting on Paleoseismology, Active Tectonics and Archeoseismology, Aachen, Germany. vol. 4 (hal-01184208).

Bertran, P., Andrieux, E., Antoine, P., Coutard, S., Deschodt, L., Gardère, P., Mercier, N., 2014. Distribution and chronology of Pleistocene permafrost features in France: database and first results. Boreas 43 (3), 699-711.

Bertran, P., Liard, M., Sitzia, L., Tissoux, H., 2016. A map of Pleistocene aeolian deposits in Western Europe, with special emphasis on France. J. Quat. Sci. 31 (8), 844-856.

Bertran, P., Andrieux, E., Antoine, P., Deschodt, L., Font, M., Sicilia, D., 2017. Pleistocene involutions and patterned ground in France: examples and analysis using a GIS database. Permafr. Periglac. Process. https://doi.org/10.1002/ppp.1957.

Bohncke, S.P.J., Bos, J.A.A., Engels, S., Heiri, O., Kasse, C., 2008. Rapid climatic events as recorded in Middle Weichselian thermokarst lake sediments. Quat. Sci. Rev. 27, 162-174.

Boyé, M., 1958. Les lagunes du plateau landais. Biul. Peryglac. 26, 195-225.

Briant, R.M., Bateman, M.D., Coope, G.R., Gibbard, P.L., 2005. Climatic control on Quaternary fluvial sedimentology of a Fenland Basin river, England. Sedimentology 52, 1397-1423.

Calmels, F., Delisle, G., Allard, M., 2008. Internal structure and the thermal and hydrological regime of a typical lithalsa: significance for permafrost growth and decay. Can. J. Earth Sci. 45, 31-43.

CIRAM, 2014. Datation par Luminescence Stimulée Optiquement (OSL) de sédiments calcaires. Séquence sédimentaire prélevée à Gourgançon. 51 (Unpublished report, Pessac, 12 pp.).

Coulon, M., 1994. Mise en évidence et approche microtectonique des déformations quaternaires en Champagne: implications géodynamiques et conséquences hydrographiques. Groupe Français de Géomorphologie, Workshop Morphogenèse cénozoïque de l'Europe de l'Ouest. Société Géologique de France, Rennes, p. 10.

Coumans, J.P., Stix, J., 2016. Caldera collapse at near-ridge seamounts: an experimental investigation. Bull. Volcanol. 78:70. https://doi.org/10.1007/s00445-016-1065-9.

Courbouleix, S., Fleury, R., 1996. Mares, mardelles et pergélisol: exemple des dépressions circulaires de Sologne. Environnements périglaciaires. 3. Association Française du Périglaciaire, pp. 63-70.

De Gans, W., 1988. Pingo scars and their identification. In: Clark, M.J. (Ed.), Advances in Periglacial Geomorphology. Wiley, Chichester, pp. 299-322.

Duller, G.A.T., 2003. Distinguishing quartz and feldspar in single grain luminescence measurements. Radiat. Meas. 37, 161-165.

Ehlers, J., Gibbard, P.L., 2004. Quaternary Glaciations. Extent and Chronology, Part I: Europe. Developments in Quaternary Science, 2a. Elsevier, Amsterdam, p. 488.

Etienne, D., Ruffaldi, P., Goepp, S., Ritz, F., Georges-Leroy, M., Pollier, B., Dambrine, E., 2011. The origin of closed depressions in Northeastern France: a new assessment. Geomorphology 126, 121-131.

Ford, D.C., 1993. Karst in cold environments. In: French, H.M., Slaymaker, O. (Eds.), Canada's Cold Environments. McGill-Queen's University Press, Montreal \& Kingston, pp. 199-222.

Fortier, D., Allard, M., Shur, Y., 2007. Observation of rapid drainage system development by thermal erosion of ice wedges on Bylot Island, Canadian Arctic Archipelago. Permafr. Periglac. Process. 18, 229-243.

French, H.M., 2007. The Periglacial Environment. 3rd edition. Wiley, Chichester (478 p).

Galbraith, R.F., Roberts, R.G., Laslett, G.M., Yoshida, H., Olley, J.M., 1999. Optical dating of single and multiple grains of quartz from Jinmium Rock Shelter, Northern Australia: part I, experimental design and statistical models. Archaeometry 41, 339-364.

Geyer, A., Folch, A., Marti, J., 2006. Relationship between caldera collapse and magma chamber withdrawal: an experimental approach. J. Volcanol. Geotherm. Res. 157, 375-386.

Guilloré, P., 1980. Méthode de fabrication mécanique et en série des lames minces. Institut National d'Agronomie, Paris-Grignon (22 pp).

Harris, C., Ross, N., 2007. Pingos and pingo scars. In: Elias, S.A. (Ed.), Encyclopedia of Quaternary Science. Elsevier, Amsterdam, pp. 2200-2207.
Hinkel, K.M., Sheng, Y., Lenters, J.D., Lyons, E.A., Beck, R.A., Eisner, W.R., Wang, J., 2012 Thermokarst Lakes on the Arctic coastal plain of Alaska: geomorphic controls on bathymetry. Permafr. Periglac. Process. 23, 218-230.

Hughes, P.D., Gibbard, P.L., 2015. A stratigraphical basis for the Last Glacial Maximum (LGM). Quat. Int. 383, 174-185.

Hughes, A.L.C., Gyllencreutz, R., Lohne, Ø.S., Mangerud, J., Svendsen, J.I., 2016. The last Eurasian ice sheets - a chronological database and time-slice reconstruction, DATED-1. Boreas 45, 1-45.

Isarin, R., Huijzer, B., van Huissteden, K., 1998. Time-slice Oriented Multiproxy Database (MPDB) for Palaeoclimatic Reconstruction. National Snow and Ice Data Center. University of Boulder, Colorado http://nsidc.org/data/ggd248.html.

Jones, B.M., Arp, C.D., 2015. Observing a catastrophic thermokarst lake drainage in Northern Alaska. Permafr. Periglac. Process. 26, 119-128.

Kadereit, A., Kind, C.J., Wagner, G.A., 2013. The chronological position of the Lohne Soil in the Nussloch loess section - re-evaluation for a European loess-marker horizon. Quat. Sci. Rev. 59, 67-86.

Kasse, K., Bohncke, S., 1992. Weichselian Upper Pleniglacial aeolian and ice-cored mor phology in the southern Netherlands (Noort-Brabant, Groote Peel). Permafr. Periglac. Process. 3 (4), 327-342.

Kokelj, S.V., Jorgenson, M.T., 2013. Advances in thermokarst research. Permafr. Periglac. Process. 24, 108-119.

Lécolle, F., 1998. Que faire des dépressions fermées? Quaternaire 9 (2), 101-104.

Legigan, P., 1979. L'élaboration de la formation du Sables des Landes. Dépôt résiduel de l'environnement sédimentaire Pliocène- Pléistocène centre aquitain. Mémoires de l'Institut de Géologie du Bassin d'Aquitaine. 9 (429 p).

Locht, J.L., Antoine, P., Auguste, P., Bahain, J.J., Debeham, N., Falguères, C., Farkh, S., Tissoux H., 2006. La séquence lœssique Pléistocène supérieur de Savy (Aisne, France): stratigraphie, datations et occupations paléolithiques. Quaternaire 17, 269-275.

Mackay, J.R., 1986. Frost mounds. In H.M. French (Ed.), focus: permafrost geomorphology. Can. Geogr. 30, 363-364

Mackay, J.R., 1988. Catastrophic lake drainage, Tuktoyaktuk peninsula area, District of Mackenzie. Current Research, Part D. Geological Survey Canada, Paper 88-1D, pp. 83-90.

Mackay, J.R., 1998. Pingo growth and collapse, Tuktoyaktuk Peninsula area, western Arctic coast, Canada: a long-term field study. Géog. Phys. Quatern. 52 (3), 271-323.

Marsh, R.E., Prestwich, W.V., Rink, W.J., Brennan, B.J., 2002. Monte Carlo determinations of the beta dose rate to tooth enamel. Radiat. Meas. 35, 193-219.

Miall, A.D., 1996. The Geology of Fluvial Deposits. Springer, Berlin (582 pp)

Michel, J.P., 1962. Description de formations quaternaires semblables à des " diapirs " dans les alluvions de la Seine et de la Marne près de Paris. Bull. Soc. Geol. Fr. S7-IV (6), 795-799.

Michel, J.P., 1967. Dépressions fermées dans les alluvions anciennes de la Seine à $100 \mathrm{~km}$ au S-E de Paris. Bull. Assoc. Fr. Etud. du Quat. (2), 131-134.

Michel, J.P., 1975. Périglaciaire des environs de Paris. Biul. Peryglac. 24, 259-352.

Morgenstern, A., Ulrich, M., Günther, F., Roessler, S., Fedorova, I.V., Rudaya, N.A. Wetterich, S., Boike, J., Schirrmeister, L., 2013. Evolution of thermokarst in East Siberian ice-rich permafrost: a case study. Geomorphology 201, 363-379.

Murray, A.S., Wintle, A.G., 2003. The single aliquot regenerative dose protocol: potential for improvements in reliability. Radiat. Meas. 37, 377-381.

Murton, J.B., 2013. Ice wedges and ice wedge casts. In: Elias, S.A., Mock, C.J. (Eds.), Encyclopedia of Quaternary Science. Elsevier, Amsterdam, pp. 436-451.

Obermeier, S.F., Olson, S.M., Green, R.A., 2005. Field occurrences of liquefaction-induced features: a primer for engineering geologic analysis of paleoseismic shaking. Eng. Geol. 76, 209-234.

Pastre, J.F., Limondin-Lozouet, N., Gebhardt, A., Leroyer, C., Fontugne, M., Krier, V., 2001 Lateglacial and Holocene fluvial records from the central part of the Paris Basin (France). In: Maddy, D., Macklin, M.G., Woodward, J. (Eds.), River basin sediment systems: archives of environmental change, Balkema, pp. 357-373.

Pissart, A., 1983. Remnants of periglacial mounds in the Hautes Fagnes (Belgium) Structure and age of the ramparts. Geol. Mijnb. 62, 551-555.

Pissart, A., 2000a. Remnants of lithalsas of the Hautes Fagnes, Belgium: a summary of present-day knowledge. Permafr. Periglac. Process. 11, 327-355.

Pissart, A., 2000b. Les traces de lithalses et de pingos connues dans le monde. Hautes Fagnes 3, 74-84

Pissart, A., Calmels, F., Wastiaux, C., 2011. The potential lateral growth of lithalsas. Permafr. Periglac. Process. 75, 371-377.

Pollard, W.H., van Everdingen, R.O., 1992. Formation of seasonal ice bodies. In: Dixon, J.C. Abrahams, A.D. (Eds.), Proceedings 22nd Binghamton Symposium in Geomorphology. John Wiley and Sons, Chichester, pp. 282-304.

Prescott, J.R., Hutton, J.T., 1994. Cosmic ray contributions to dose rates for luminescence and ESR dating: large depths and long-term variations. Radiat. Meas. 23, 497-500.

Rasmussen, S.O., Bigler, M., Blockley, S.P., Blunier, T., Buchardt, S.L., Clausen, H.B., Cvijanovic, I., Dahl-Jensen, D., Johnsen, S.J., Fischer, H., Gkinis, V., Guillevic, M., Hoek, W.Z., Lowe, J.J., Pedro, J., Popp, T.J., Seierstad, I.K., Steffensen, J.P., Svensson, A., Vallelonga, P.T., Vinther, B.M., Walker, M.J.C., Wheatley, J.J., Winstrup, M., 2014. A stratigraphic framework for abrupt climatic changes during the Last Glacial period based on three synchronized Greenland ice-core records: refining and extending the INTIMATE event stratigraphy. Quat. Sci. Rev. 106, 14-28.

Reimer, P.J., Bard, E., Bayliss, A., Beck, J.W., Blackwell, P.G., Bronk Ramsey, C., Buck, C.E., Cheng, H., Edwards, R.L., Friedrich, M., Grootes, P.M., Guilderson, T.P., Haflidason, H., Hajdas, I., Hatté, C., Heaton, T.J., Hoffmann, D.L., Hogg, A.G., Hughen, K.A., Kaiser, K.F., Kromer, B., Manning, S.W., Niu, M., Reimer, R.W., Richards, D.A., Scott, E.M. Southon, J.R., Staff, R.A., Turney, C.S.M., van der Plicht, J., 2013. Intcal13 and Marine13 radiocarbon age calibration curves 0-50,000 years cal BP. Radiocarbon 55 (4), 1869-1887. 
Roche, O., van Wyk de Vries, B., Druitt, T.H., 2001. Sub-surface structures and collapse mechanisms of summit pit. J. Volcanol. Geotherm. Res. 105, 1-18.

Rodet, J., 2013. Karst et évolution géomorphologique de la côte crayeuse à falaises de la manche. L'exemple du massif d'aval (Etretat, Normandie, France). Quaternaire 24 (3), 303-314.

Ross, N., Harris, C., Brabham, P.J., Sheppard, T.H., 2011a. Internal structure and geological context of ramparted depressions, Llanpumsaint, Wales. Permafr. Periglac. Process. 22 (4), 291-305.

Ross, J.A., Peakal, J., Keevil, G.M., 2011b. An integrated model of extrusive sand injectites in cohesionless sediments. Sedimentology 58, 1693-1715.

Sanford, A.R., 1959. Analytical and experimental study of simple geologic structures. Bull. Geol. Soc. Am. 70, 19-52.

Seppälä, M., 1997. Piping causing thermokarst in permafrost, Ungava Peninsula, Québec, Canada. Geomorphology 20, 313-319.

Sitzia, L., 2014. Chronostratigraphie et distribution spatiale des dépôts éoliens du Bassin Aquitain. (PhD Thesis). Université de Bordeaux, Bordeaux, p. 341.

Steedman, A.E., Lantz, T.C., Kokelj, S.V., 2016. Spatio-temporal variation in high-centre polygons and ice-wedge melt ponds, Tuktoyaktuk coastlands, Northwest Territories. Permafr. Periglac. Process. https://doi.org/10.1002/ppp.1880.

Texier, J.P., 2011. Genèse des lagunes landaise: un point sur la question. In: Merlet, J.C., Bost, J.P. (Eds.), De la lagune à l'airial, Aquitania suppl. 24, pp. 23-42.

Thakkar, M.G., Goyal, B., Maurya, D.M., Chamyal, L.S., 2012. Internal geometry of reactivated and non-reactivated sandblow craters related to 2001 Bhuj earthquake, India: a modern analogue for interpreting paleosandblow craters. J. Geol. Soc. India 79, 367-375.

Van Huissteden, J., Kasse, C., 2001. Detection of rapid climate change in the Last Glacial fluvial successions in The Netherlands. Glob. Planet. Chang. 28, 319-339.

Van Vliet, B., Langohr, R., 1981. Correlation between fragipans and permaforst with special reference to silty Weichselian deposits in Belgium and northern France. Catena 8, 137-154.

Van Vliet-Lanoë, B., 1992. Le niveau à langues de Kesselt, niveau repère de la stratigraphie du Weichsélien supérieur européen: signification paléoenvironnementale et paléoclimatique. Soc. Géol. Fr. Mém. 160, 35-44.
Van Vliet-Lanoë, B., Brulhet, J., Combes, C., Duvail, C., Ego, F., Baize, S., Cojan, I., 2016. Quaternary thermokarst and thermal erosion features in northern France: origin and palaeoenvironments. Boreas https://doi.org/10.1111/bor.12221.

Vandenberghe, J., 1992. Cryoturbations: a sediment structural analysis. Permafr. Periglac. Process. 3, 343-352.

Vandenberghe, J., 2008. The fluvial cycle at cold-warm-cold transitions in lowland regions: a refinement of theory. Geomorphology 98, 275-284.

Vandenberghe, J., 2013. Cryoturbation structures. In: Elias, S.A., Mock, C.J. (Eds.), Encyclopedia of Quaternary Science. Elsevier, Amsterdam, pp. 430-435.

Walter, T.R., Troll, V.R., 2001. Formation of caldera periphery faults: an experimental study. Bull. Volcanol. 63, 191-203.

Watson, E., 1971. Remains of pingos in Wales and the Isle of Man. Geol. J. 7, 381-392.

Wolfe, S.A., Stevens, C.W., Gaanderse, A.J., Oldenborger, G.A., 2014. Lithalsa distribution, morphology and landscape associations in the Great Slave Lowland, Northwest Territories, Canada. Geomorphology 204, 302-313.

Worsley, P., Gurney, S.D., 1996. Geomorphology and hydrogeological significance of the Holocene pingos in the Karup Valley area, Traill Island, northern east Greenland. J. Quat. Sci. 11, 249-262.

Wünnemann, B., Reinhardt, C., Kotlia, B.S., Riedel, F., 2008. Observations on the relationship between lake formation, permafrost activity and lithalsa development during the last 20000 years in the Tso Kar Basin, Ladakh, India. Permafr. Periglac. Process. 19, 341-358

Yoshikawa, K., 1993. Notes on open-system pingo ice, Adventdalen, Spitsbergen. Permafr. Periglac. Process. 4 (4), 327-334.

Yoshikawa, K., Hinzman, L.D., 2003. Shrinking thermokarst ponds and groundwater dynamics in discontinuous permafrost near Council, Alaska. Permafr. Periglac. Process. 14, 151-160.

Youd, T.L., 1973. Liquefaction, flow, and associated ground failure. U.S. Geological Survey Circular. 688 (12 pp.) 